University of Nebraska - Lincoln

DigitalCommons@University of Nebraska - Lincoln

Faculty Publications: Department of Entomology

2022

\title{
Death Scene Insect Succession in Nebraska: A Guidebook
}

\author{
Erin Bauer \\ University of Nebraska-Lincoln, ebauer2@unl.edu \\ Larry Barksdale \\ University of Nebraska-Lincoln, larry.barksdale@unl.edu \\ Emma Sidel \\ University of Nebraska-Lincoln \\ Justine LaViolette \\ University of Nebraska - Lincoln, justinelav@huskers.unl.edu
}

Follow this and additional works at: https://digitalcommons.unl.edu/entomologyfacpub

Part of the Entomology Commons, Forensic Science and Technology Commons, and the Other Anthropology Commons

Bauer, Erin; Barksdale, Larry; Sidel, Emma; and LaViolette, Justine, "Death Scene Insect Succession in Nebraska: A Guidebook" (2022). Faculty Publications: Department of Entomology. 983.

https://digitalcommons.unl.edu/entomologyfacpub/983

This Article is brought to you for free and open access by the Entomology, Department of at DigitalCommons@University of Nebraska - Lincoln. It has been accepted for inclusion in Faculty Publications: Department of Entomology by an authorized administrator of DigitalCommons@University of Nebraska - Lincoln. 

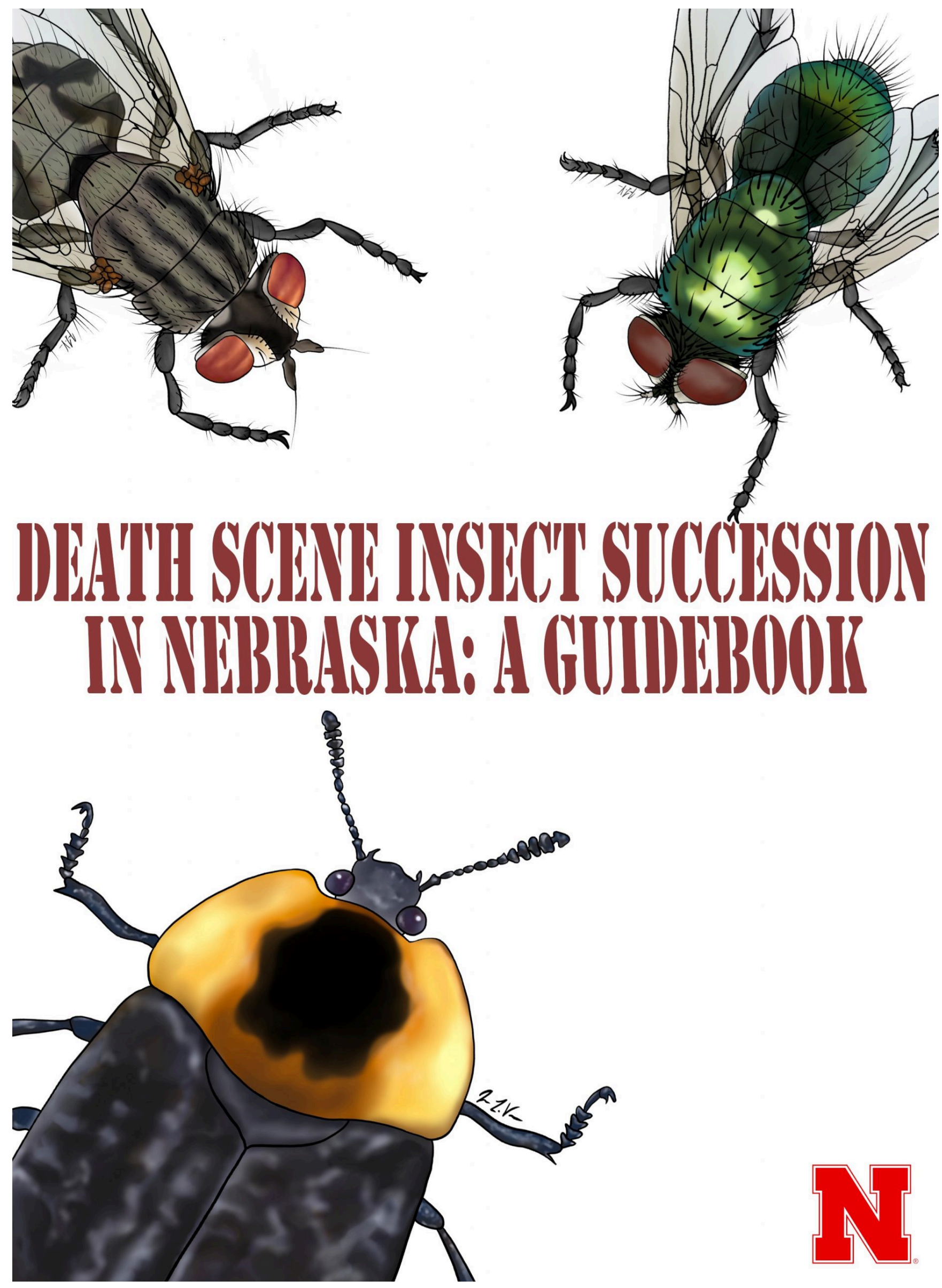


\section{Death Scene Insect Succession in Nebraska: A Guidebook}





\section{DEATH SCENE INSECT SUCCESSION IN}

NEBRASKA: A GUIDEBOOK

ERIN BAUER; LARRY BARKSDALE; EMMA SIDEL; AND ILLUSTRATIONS BY JUSTINE LAVIOLETTE 


\section{() (1) $(3$}

Death Scene Insect Succession in Nebraska: A Guidebook by University of Nebraska-Lincoln is licensed under a Creative Commons Attribution-NonCommercial 4.0 International License, except where otherwise noted.

The University of Nebraska does not discriminate based on race, color, ethnicity, national origin, sex, pregnancy, sexual orientation, gender identity, religion, disability, age, genetic information, veteran status, marital status, and/or political affiliation in its programs, activities, or employment.

If reusing, please credit Erin Bauer \& Larry Barksdale at the University of Nebraska-Lincoln.

This book was produced with Pressbooks (https://pressbooks.com) and rendered with Prince.

doi:10.32873/unl.dc.oth.012 


\section{CONTENTS}

Acknowledgements $\quad$ ix

Introduction 1

PART I. OVERVIEW

History of Forensic Entomology $\quad 5$

Decomposition and Types of Insects 6

PART II. SELECTED FORENSIC INSECT DESCRIPTIONS

$\begin{array}{ll}\text { Flies (Order: Diptera) } & 11\end{array}$

$\begin{array}{ll}\text { Beetles (Order: Coleoptera) } & 13\end{array}$

$\begin{array}{ll}\text { Miscellaneous Predatory Insects } & 17\end{array}$

$\begin{array}{lr}\text { Opportunistic Insects } & 18\end{array}$

PART III. CASE STUDIES

$\begin{array}{ll}\text { Case Study } 1 & 23\end{array}$

$\begin{array}{lr}\text { Case Study } 2 & 28\end{array}$

PART IV. PROCESSING THE DEATH SCENE STEP-BY-STEP

Processing the Death Scene Step-by-Step 39

PART V. CONCLUSION

PART VI. APPENDIX A: FORENSIC ENTOMOLOGY EXERCISES

Forensic Insect Succession Case Studies

Forensic Insect Identification $\quad 49$

Collecting and Preserving Insects at Crime Scenes $\quad 50$

Bloodstains/Insect Artifacts 
Postmortem Interval (aka Time Since Death)

Insect Color Preference

PART VII. APPENDIX B: FORMS AND EXERCISES

Creating a Kill Jar 57

Scene Collection Notes Worksheet 58

Additional References and Resources

61

Books and Other Media about Forensic Entomology or Forensic Insect 63 Identification

Glossary 


\section{ACKNOWLEDGEMENTS}

A special thanks to Beth Butin, University of Nebraska-Lincoln (UNL) Forensic Entomology adjunct Professor; Vilma Montenegro Castro, Lindsey McNaughten, and Sydney Stoopes, entomology graduate students; and Haley Fleetwood, forensic science undergraduate student, for their review of this guidebook and valuable comments and suggestions. Thanks also to Britaney Hight, entomology graduate student, for her layout and design of this manual and Justine LaViolette, UNL Entomology Department alumna, for her insect illustrations and for her participation in this research project.

Copyright 2022 



\section{INTRODUCTION}

Insect behavior can be helpful to law enforcement in determining time of death, manner of death, location, and environment related to human or other animal victims found at a death scene. They may also provide clues about other aspects associated with an investigation (i.e., fly specks, suspect DNA). The study of how insects and related arthropods can aid in legal investigations is known as forensic entomology. Although this includes both civil applications, such as urban (i.e., maggots in mortuaries or insect structural damage) or stored product (i.e., illness from food contamination) entomology, this manual focuses on criminal applications, such as how insect evidence can be used at death scene investigations.

One of the most important uses of entomological evidence for crime scene cases is in estimating time since death, or postmortem interval (PMI). Another related term, which is sometimes used interchangeably with PMI, and in other cases is used separately, is "time since colonization." This is the time at which insects first colonize a dead body. Because blow flies visit a body often within minutes of death, it is reasonable that this would coincide with PMI. However, it is important to note that due to other factors such as temperature, location, weather conditions, and other variables, insect activity can accelerate or slow down and thus influence PMI. PMI can even be set back if animal predators find a corpse and feed on the flesh, inadvertently eating or destroying any insect eggs that have been laid on it. In this case, the earliest eggs to hatch on a body may be the offspring of insects that arrived later in the decomposition process rather than from initial insect visitors. If the body appears damaged by predator activity, the possibility of early colonizer larvae having been destroyed should be taken into consideration when making PMI estimations.

The life stages of insects found on a corpse can give clues about how long the person has been dead and help build a timeline of the crime. While this guidebook will not be detailing how to calculate PMI, references are included at the end that will provide this information for law enforcement who may be doing this work. Investigators may also wish to consult a forensic entomologist specializing in this area for assistance.

This guidebook discusses the general succession of forensically important insects expected to populate a decomposing body found in an outdoor environment during the summer months in Lincoln, Nebraska. There are limitations to generalizing this location with other locations. However, we are of the opinion that the information is useful for a general protocol for decomposition scenes be they murder, suicide, accidental, undetermined, natural, human, or non-human.

This guide emphasizes what entomological evidence to look for at a death investigation, how to properly document evidence with photographs/temperature and humidity loggers/field notes, how to collect and preserve insect specimens, how to do preliminary analysis of insects and remains, how to decide whether to solicit an expert, and how to submit insect evidence for analysis. The more information and data that is available, the better it will be for an accurate and useful report.

After a brief discussion about the history of forensic entomology, this manual is divided into several sections. The first section will examine the stages of decomposition and the types of insects that visit a corpse during these different decomposition stages. The second will provide detailed descriptions of some of the most common forensically important insect orders. The third section presents two field exercises as case studies illustrating the process of decomposition and insect behavior. The final section will examine the step by step process for collecting and preserving insects at a crime scene and the type of information that insect evidence can tell investigators. A references/resources list is available, as well as practice exercises to test your knowledge. 

PART I.

OVERVIEW

DEATH SCENE INSECT SUCCESSION IN NEBRASKA 3 



\section{HISTORY OF FORENSIC ENTOMOLOGY}

Before delving into the practical aspects and applications of forensic entomology, it's important to know a bit about its history. One of the earliest uses of forensic entomology can be traced back to Sung Tzu, a lawyer and investigator in 1235 China. He wrote The Washing Away of Wrongs, which laid the foundation for forensic entomology. He once investigated a murder that was committed by slashing and asked the local villagers to place their sickles on the ground. Flies were attracted to one sickle (conceivably covered with blood and other remains of the victim), and the murderer confessed (Gennard, 2012).

Another historical account comes from 1855 when French doctor Bergeret d'Arbois investigated the discovery of an infant in the wall of a house. Based on the development times of insects found in the body (pupae of flies and moths), he found the baby had died several years before, thereby proving the current tenants innocent and leading to the arrest of the previous homeowners (Gennard, 2012).

French army veterinarian Jean Pierre Mégnin is credited with writing one of the early books on insect succession and decomposition in humans, La Faune des Cadavres (Beneke, 2001). These early examples demonstrate the importance of forensic entomology, and although the field is still growing, it has aided in solving many cases in recent years (Gennard, 2012). 


\section{DECOMPOSITION AND TYPES OF INSECTS}

\section{OVERVIEW}

Insects are an essential part of the decomposition process. The process follows several stages: fresh, bloated, active decay, post decay, and skeletal. Insects aid bacteria in the breakdown of dead plant and animal matter (Australian Museum \& Forensic Library, n.d.). Certain insects, like blow flies, are attracted to odors that are produced once an organism dies, and thus are quickly drawn to a body. Researchers have determined that necrophagous insects, those that feed directly on animal remains and related fluids, can detect and arrive at a corpse within minutes (Rivers \& Dahlem, 2014). Others, such as rove beetles, come to a body as predators to exploit other insects. A predictable pattern of insect succession is known to occur, although species can overlap. Insects will visit the body, lay eggs, feed on the remains, predate on other insects, or remain in the area because it is their natural environment.

Although insects normally visit corpses in a predictable pattern, factors such as climate, temperature, seasons, storms, physical barriers, cadaver size and status, and locations can influence their ability to interact with a corpse and affect the decomposition process. For example, a corpse outside in the winter would not decompose as quickly as one lying outside in the summer. Insects are not active in an outdoor, cold environment and thus would find the body after the thaw when the warmer conditions would be better suited to them. Similarly, a corpse openly exposed in a sunny area would be more easily accessible to insects than a corpse tightly wrapped in a tarp. An outdoor rural environment would provide a greater variety of arthropod orders, as opposed to remains decomposing in a residence or urban environment. The weight of a corpse can affect decomposition rates. A child that weighs 30 pounds would, with normal insect activity and under normal environmental conditions, take far less time to decompose than a 200-pound man. Finally, the status of a corpse could affect insect activity. For example, a mummified body would provide less food for insects than a fresh corpse.

Generally, flies are present at decomposition scenes and give information useful for calculating time of death. The different variables can affect the progression of the fly life cycle. The times of the life cycle stages are the measurements for determining times since death.

Before examining in more detail what types of insects appear on or near a corpse in our case studies, the stages of decomposition should be discussed. Please note that some resources combine some of these stages or have different names, but the general process is still the same. Also, the stages themselves may overlap within the same body or last longer or shorter periods of time depending on environmental conditions.
For purposes of this guidebook, these are the five stages:

\section{Stage 1: Fresh/Initial (0-3 days)}

During this period, the body looks relatively unchanged from life, but within minutes of death, blow flies will begin to appear and land near and on the body. Autolysis (cellular breakdown) begins, and the body may show signs of livor mortis (pooling of blood within the body), rigor mortis (muscle stiffening), and algor mortis (reduction in body temperature) (Forensics Library, n.d.). Odors may not seem putrid at this point to humans, but the body will be emitting odors that flies sense and are attracted to.

\section{Stage 2: Bloated (2-6 days)}

The corpse will show obvious signs of decomposition, such as bodily bulging or protrusion due to gasses building up from bacterial activity. The skin may be marbled (have a pattern of discoloration). A putrid odor may be evident at this stage. Flies should be prevalent, and large numbers of maggots will be present. Predatory arthropods may also be present as well as some opportunistic insects (i.e., butterflies feeding on bodily fluids).

\section{Stage 3: Active Decay (5-11 days)}

The corpse deflates and releases odorous gasses. This is very attractive to insects. Maggots should still be very active at this point, with various larval instars present. Some maggots may still be new if eggs were laid later. The earliest hatched maggots may be starting to migrate off the body to pupate. Predatory arthropods such as ants are likely present as well as carrion beetles.

\section{Stage 4: Post Decay/Remains (10-24 days)}

Bones and some skin/hide may be present, but most of the flesh should be gone by this stage. Flies and maggots will be mostly gone. Predatory insects, such as ants, may still be around, as well as some dermestid and carrion beetles. Incidentals such a field crickets may be present around the remains.

\section{Stage 5: Skeletal (24+)}

By now, the remains are just bones. Some dermestid beetles may still be present, but otherwise, the body is decomposed, and other insects would be incidental.

Insects visit the corpse in a successional way, depending upon the stage of decomposition. In the chart below (Figure 1 ), the types of insects found on or near a body in relation to stages of succession is listed (information compiled based 
on Byrd \& Tomberlin, 2020; Byrd \& Castner, 2010). Please note that this is a general timeline, there can be an overlap of species in some stages. Also be aware that these decomposition stages are for corpses found on land that experience normal weather and climatic patterns. In other environments, such as aquatic systems or the extremely dry conditions that lead to mummification, these stages may vary.
Type of Insect

Stage of Decomposition

Activity

\begin{tabular}{|c|c|c|}
\hline Blow Flies & Fresh/initial stage, even within minutes of death & $\begin{array}{l}\text { Lay eggs, especially in natural openings such as nose, } \\
\text { eyes, mouth, anus, genitals; may lay eggs in wounds if } \\
\text { present }\end{array}$ \\
\hline $\begin{array}{l}\text { Maggots } \\
\text { (blow fly } \\
\text { larvae) }\end{array}$ & $\begin{array}{l}\text { Fresh/initial, bloated, active decay (mostly) and post } \\
\text { decay; collecting maggots and determining stage of } \\
\text { development is helpful in estimating time since death }\end{array}$ & Feed on the corpse, help break it down \\
\hline Flesh Flies & $\begin{array}{l}\text { Can arrive within minutes, especially in inclement } \\
\text { weather when blow flies are not active, then later on } \\
\text { in decay process; lay live larvae }\end{array}$ & $\begin{array}{l}\text { Female retains eggs inside until they hatch, then lay live } \\
\text { larvae on the corpse. They will arrive during active decay } \\
\text { but may produce offspring later than blow flies. }\end{array}$ \\
\hline $\begin{array}{l}\text { Carrion } \\
\text { Beetles }\end{array}$ & Active and post decay & Feed on a corpse or lay eggs in it. \\
\hline $\begin{array}{l}\text { Predatory } \\
\text { Arthropods }\end{array}$ & $\begin{array}{l}\text { Once maggots emerge, many predatory insects will } \\
\text { show up. }\end{array}$ & $\begin{array}{l}\text { Arthropods such as ants, spiders, wasps, and earwigs } \\
\text { appear to feed on maggots, both those on the body and } \\
\text { those that are migrating away from the body. }\end{array}$ \\
\hline $\begin{array}{l}\text { Predatory } \\
\text { Beetles }\end{array}$ & $\begin{array}{l}\text { If maggots are present, predatory beetles will be } \\
\text { present. }\end{array}$ & $\begin{array}{l}\text { Hister beetles, red-legged ham beetles, rove beetles, and } \\
\text { other species may feed on maggots or other insects on or } \\
\text { near the body }\end{array}$ \\
\hline $\begin{array}{l}\text { Other } \\
\text { Arthropods }\end{array}$ & $\begin{array}{l}\text { During any stage, these may be incidental arthropods } \\
\text { and other animals. Their natural habitat is the } \\
\text { environment where the body is located. They may } \\
\text { feed on bodily fluids. }\end{array}$ & $\begin{array}{l}\text { Spiders, small "gnat-like" flies, moths, bees, crickets, } \\
\text { sowbugs, butterflies. }\end{array}$ \\
\hline $\begin{array}{l}\text { Dermestid } \\
\text { Beetles }\end{array}$ & $\begin{array}{l}\text { Remains and skeletal, mostly dried out with just hide } \\
\text { and bones; adults may be present in earlier stages, } \\
\text { but larvae feed on dried remains. }\end{array}$ & $\begin{array}{l}\text { Dermestids such as hide beetles feed on the dried-out } \\
\text { remains, such as the hide and what's left on the bones }\end{array}$ \\
\hline
\end{tabular}

Figure 1: Chart of Insect Succession

\section{MUMMIFICATION}

Mummification occurs when a body is exposed to extremely warm, or extremely cold, arid conditions. These conditions cause the body to desiccate and remain generally intact. The corpse will be "fairly well preserved compared to cadavers that have undergone the 'typical' decomposition process, appearing brown in colour with shrivelled, leatherlike skin, retaining certain aspects of the appearance" (Forensic Library, n.d.).

\section{AQUATIC SYSTEMS}

A body that is found in water will be in an " $\mathrm{N}$ " shape, with the head down, bum in the air, knees down, and feet facing upward. It will have a different decomposition rate than someone left on land, such as in a field or buried. Decomposition can also be affected by the $\mathrm{pH}$ of the water, clothing, biomass, and aquatic scavengers. Bacterial and alveolar macrophages (used to see if someone has drowned or murdered somewhere else and then dumped in water) feed on the body. Insects more commonly found on corpses on dry land, such as flies, will largely be absent unless the body remains exposed above the surface for long periods of time without sinking or being swept away by currents.

PMI for a water-logged body is known as PMSI (postmortem submergence interval) and represents the time the corpse was dumped in water until the time of its discovery. According to Gennard (2012), stages of decomposition for an aquatic corpse are as follows:

- Submerged fresh stage (sink) - body is still in N-shape; over time the body produces gasses and buoyancy

- Floating decay stage (may depend on temperatures, if it's too cold the body stays submerged, if warmer it will pop up)

- Bloated deterioration stage-the body has produced enough gas that it is fully bloated

- Sunken and/or floating remains-depending on the temperature of the water, the body will either sink or float

- Other physical changes: maceration (pruny fingers), lost nails, rigor mortis, hypostasis (livor mortis), putrefaction slows (water colder) 

PART II.

\section{SELECTED FORENSIC INSECT DESCRIPTIONS}

Below are photos and information about some groups of insects that may visit a body. This is not comprehensive. It covers some of the major orders and species you may find. 



\section{FLIES (ORDER: DIPTERA)}

\section{BLOW FLY (FAMILY: CALLIPHORIDAE)}

Blow flies, which are about the size of a house fly (8-10 $\mathrm{mm}$ ), include common species such as green or blue bottle flies. They are often metallic and come in green, gold, blue, or black. Some calliphorids are confused with sarcophagids (flesh flies); however, blow flies are often metallic and have the last antennal segment plumose (feathery) at the tip.

Blow flies exhibit complete metamorphosis with four stages: egg, three larval instars (maggots), pupa, and adult. Some species of blow flies lay their eggs in open sores of animals and people (Triplehorn \& Johnson, 2005). Eggs are laid on dead animals and take between 18-21 hours to hatch, depending on temperature. Maggots, which have mouth hooks, feed on flesh throughout their larval stage. The larval development takes around four days at $68^{\circ} \mathrm{F}$ and three days at $80.6^{\circ} \mathrm{F}$. Once they reach the third instar, they will begin falling off the carcass and move away (up to $25 \mathrm{ft}$ ) from the body to pupate.

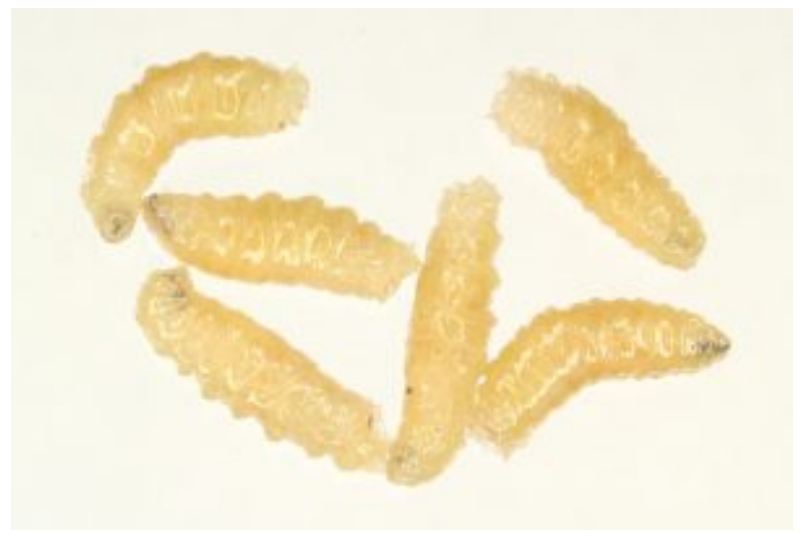

Blowfly maggots. photo: Jim Kalisch, UNL

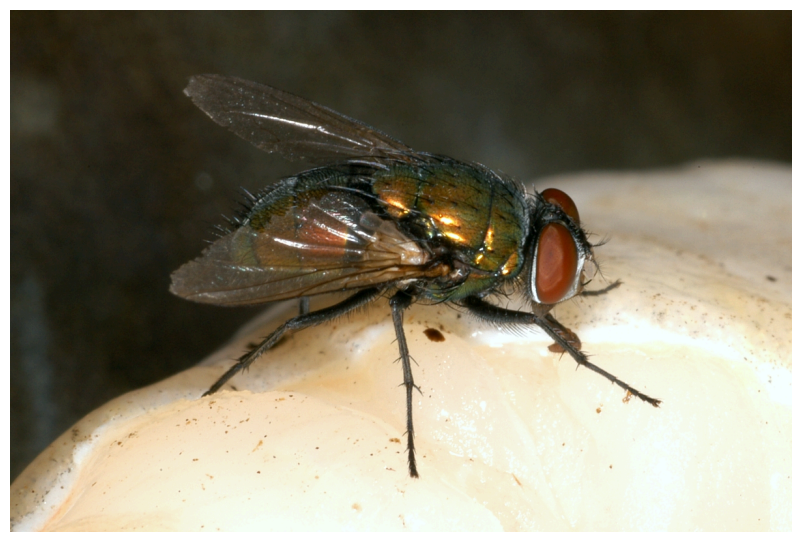

Green bottle fly. Photo: Jim Kalisch, UNL

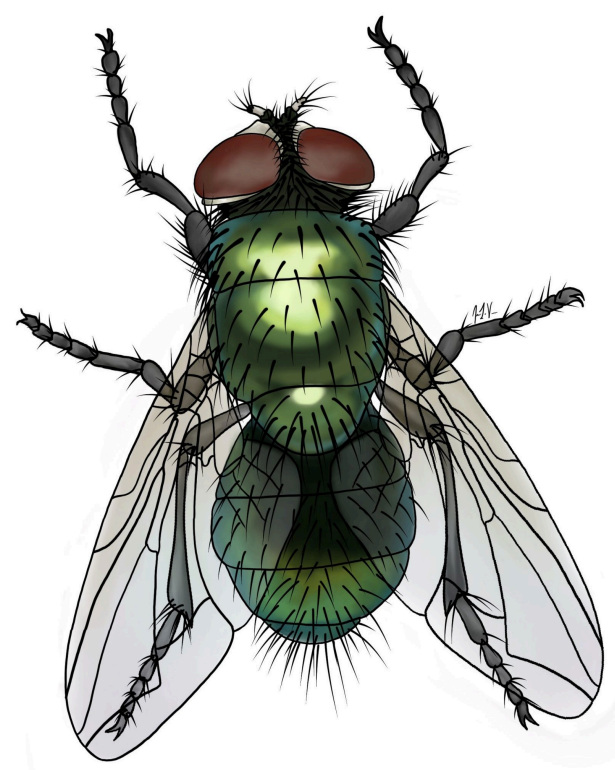

Blow fly illustration: Justine LaViolette 


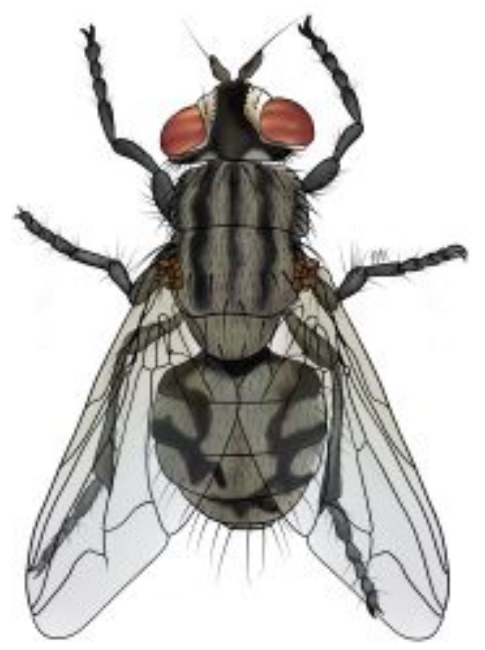

Flesh fly illustration: Justine LaViolette

\section{FLESH FLY (FAMILY: SARCOPHAGIDAE)}

Flesh fly adults are 9-13 $\mathrm{mm}$ and generally blackish with gray stripes along their thorax. Males are hairier than females. Adults are common insects which feed in diverse sugarcontaining materials (Triplehorn \& Johnson, 2005). The larvae also vary in habitats, but most of them feed on animal material. They usually hatch within the female fly, and then she deposits them on an appropriate food source, such as a

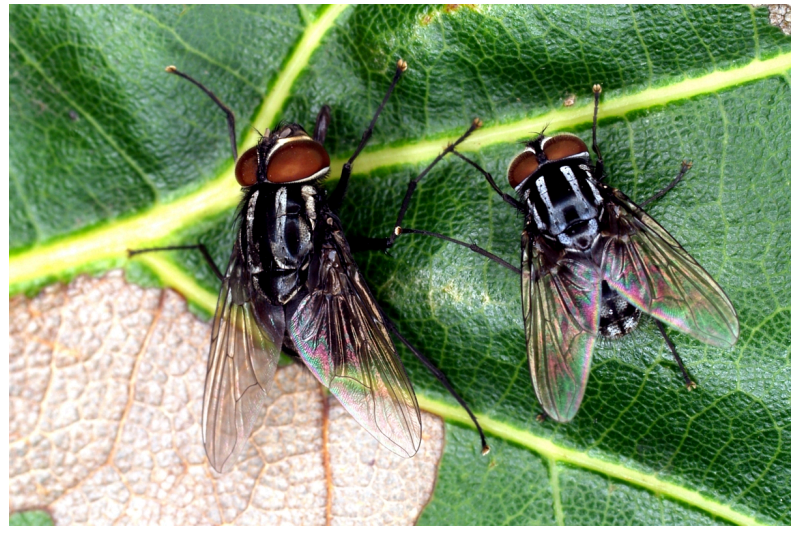

Flesh flies Photo: Jim Kalisch, UNL
Blow Fly References:

Anderson, M. \& Kaufman, P.E. "Featured Creatures: Common Green Bottle Fly." University of Florida. Retrieved from

http://entnemdept.ufl.edu/creatures/livestock/flies/lucilia_sericata.htm

Iowa State University Extension and Outreach. "Blow and Flesh Flies." Retrieved from https://hortnews.extension.iastate.edu/blow-and-flesh-flies.

Rivers, D. es Dahlem, G.A. (2014). The Science of Forensic Entomology. WileyBlackwell.

University of Maine Home and Garden IPM from Cooperative Extension. "Blow Flies and Flesh Flies." Retrieved from

https://extension.umaine.edu/home-and-garden-ipm/fact-sheets/common-name-

listing/blow-flies-and-flesh-flies/ dead animal or human. This internal hatching and subsequent deposition resembles "live birth." These flies have three instars that develop quickly on the host. Like blow flies, the third instar will leave the food resource to pupate. Development from first to third instar usually takes about 5 days.

Although not as prevalent as blow flies, finding this species can help determine PMI in forensic investigation since these flies do colonize bodies.

University of Nebraska-Lincoln Department of Entomology. "Blow Flies." Retrieved January 29, 2021 at https://entomology.unl.edu/images/blowflies

Flesh Fly References:

Diaz, L.A. es Kaufman, P.E. "Featured Creatures: Flesh Fly." University of Florida. Retrieved from

http://entnemdept.ufl.edu/creatures/misc/flies/sarcophaga_crassipalpis.htm

Texas A es M Agrilife Extension. "Blow Fly. Field Guide to Common Texas Insects." Retrieved from https://texasinsects.tamu.edu/diptera/blow-fly/ 


\section{BEETLES (ORDER: COLEOPTERA)}

\section{HISTER BEETLE (FAMILY: HISTERIDAE)}

Adult hister beetles are black and about 1.6-2.7 $\mathrm{mm}$ in length. The backs of their elytra, or wing covers, are lined. These beetles prey on fly eggs and larvae; therefore, they are not attracted to the corpse specifically. They visit the dead bodies to feed on the other insects of forensic importance.

\section{CHECKERED BEETLES (FAMILY: CLERIDAE)}

\section{Red-legged Ham Beetle}

Adult red-legged ham beetles are 3.5-7 $\mathrm{mm}$ long and bluish/black color with red legs. Both adults and larvae are predatory and may be found on or near a body feeding on maggots.
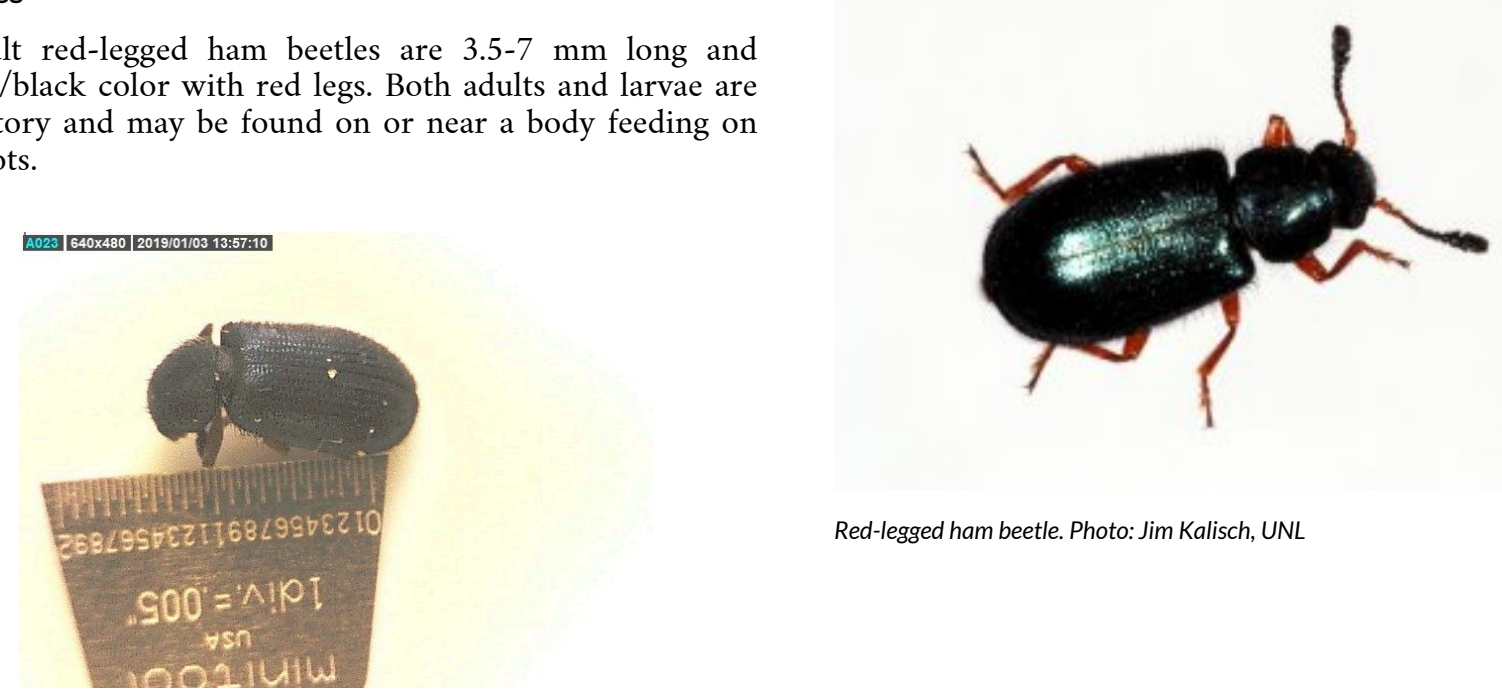
3.0 License.

Susan Ellis, USDA APHIS PPQ, Bugwood.org licensed under a Creative Commons Attribution

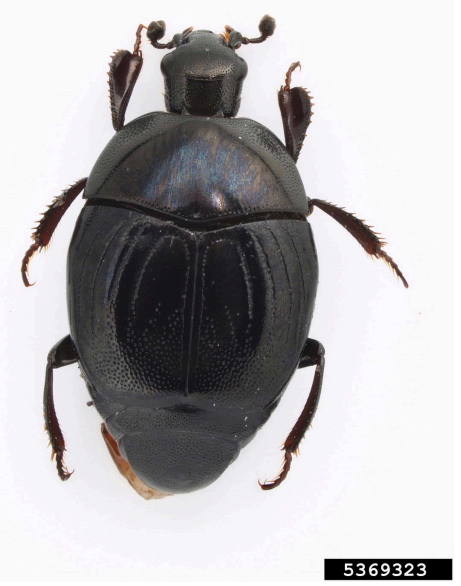

Red-legged ham beetle. Photo: Ali Hammel 


\section{Red-Shouldered Ham Beetle}

Red-shouldered ham beetles are a type of carrion predator. The adults arrive at the corpse late in the decomposition process. They feed on the carrion (mostly the drier parts such as the skin and tendons). The adults lay eggs in and on the corpse-similar to flies-and the eggs hatch into dermestid larvae which continue the cycle (Australian Museum, 2019).

\section{ROVE BEETLES (FAMILY: STAPHYLINIDAE)}

Rove beetles either feed on organic matter such as decaying vegetation or are predatory beetles both in their larval and adult stages. They are opportunistic predators at a death scene, feeding on maggots or other insects near or on the body.

Adult rove beetles are dark in color, including blacks and browns, and in the case of the hairy rove beetle, black and cream/grey. Unlike most other beetles, many rove beetle species have short elytra (hindwings) that only cover part of their body. Most species are 2-8 $\mathrm{mm}$, but larger species can be up to $35 \mathrm{~mm}$. They may curl the end of their abdomen up in a defensive posture when disturbed.

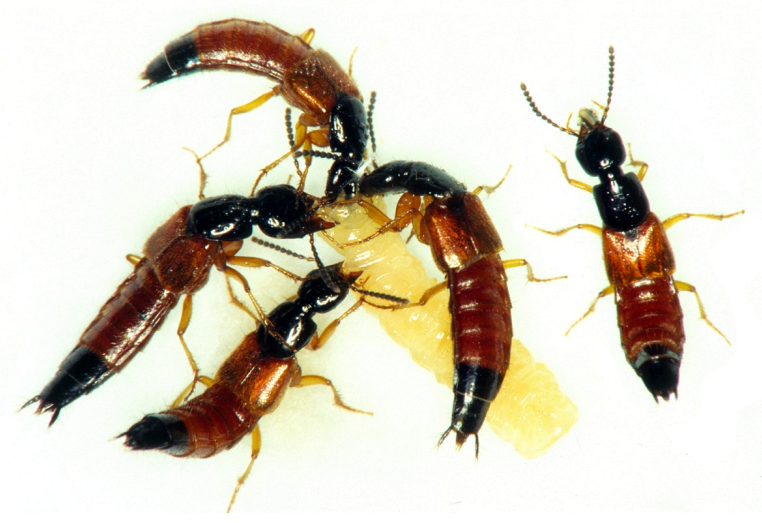

Rove beetles attacking maggot. Photo: Jim Kalisch, UNL

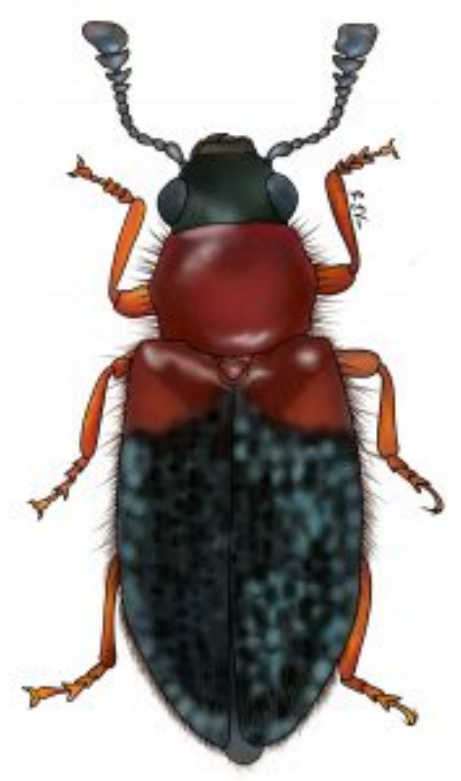

Red-shouldered ham beetle. Illustration: Justine LaViolette

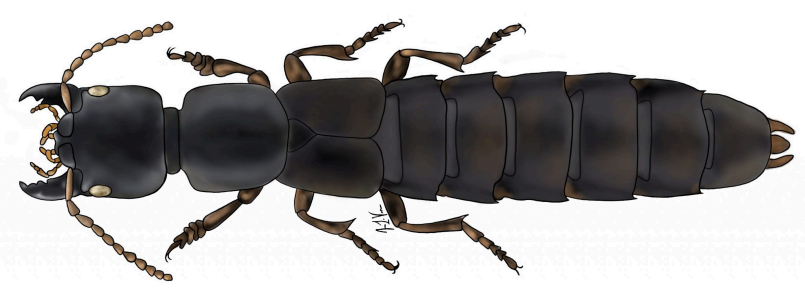

Rove beetle. Illustration: Justine LaViolette

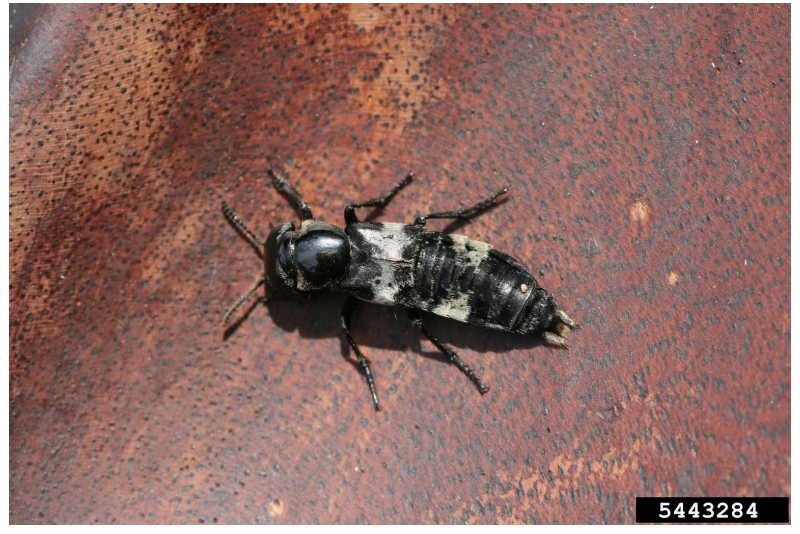

Hairy Rove Beetle: Whitney Cranshaw, Colorado State University, Bugwood.org licensed under a Creative Commons Attribution 3.0 License. 


\section{CARRION BEETLES (FAMILY: SILPHIDAE)}

\section{American Burying Beetles}

American burying beetles are an endangered species in North America. They can reach up to 2 inches and are orange and black with orange spots on the wing covers like many other carrion beetles. They also have an orange spot on their pronotum (area behind the head), which is different than other carrion beetles, and on the head between the eyes. Their antennae have a bulb at the end.

These beetles are nocturnal and will search for small carcasses (such as mice). When they find one, they will bury it and lay eggs on it. This carcass will then feed the young when they hatch.

Because these beetles are attracted to dead bodies, they may be found near and around larger corpses, like humans, too.

\section{American Carrion Beetle}

American carrion beetles are primarily black and have a yellow thorax with a black spot in the middle. They are about $12-22 \mathrm{~mm}$ in size. These beetles prey on fly eggs and larvae; therefore, they are not attracted to the corpse specifically. They visit the dead bodies to feed on the other insects of forensic importance.

There are several other silphid beetles that can be found near a body. See Carrion Beetles of Nebraska publication in the references for additional species.

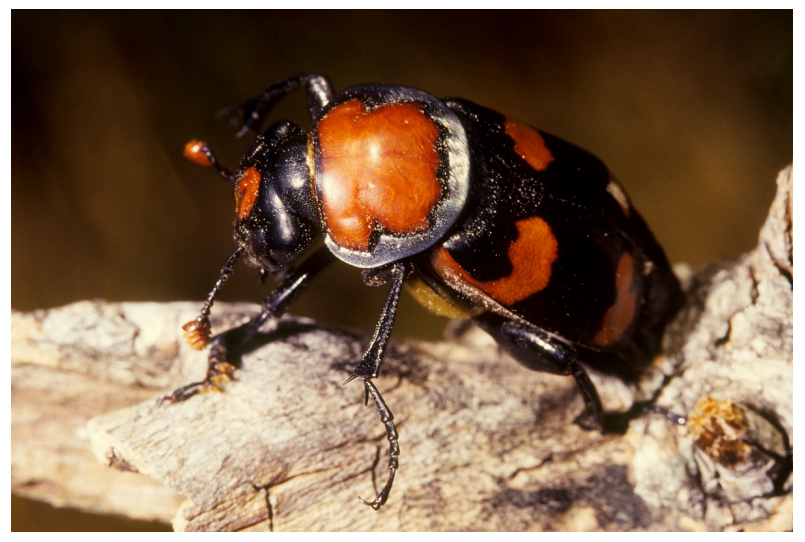

American burying beetle. Photo: Leon Higley

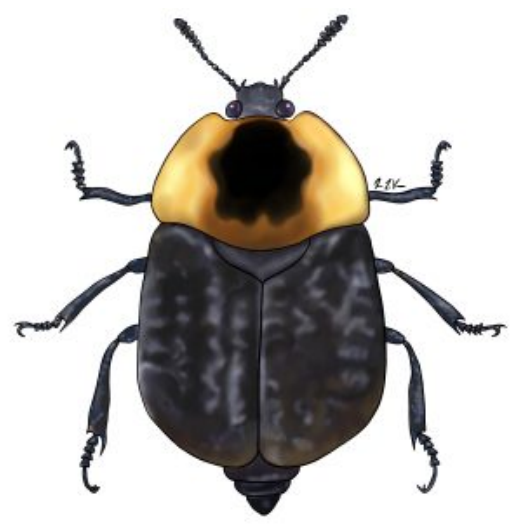

American carrion beetle. Illustration: Justine LaViolette

\section{DERMESTID BEETLES (FAMILY: DERMESTIDAE)}

\section{Hide Beetles}

Hide beetles feed on the dry skin remains of corpses. Although adults may arrive earlier, larvae are found late in the decomposition process and are the life stage used to help with PMI.

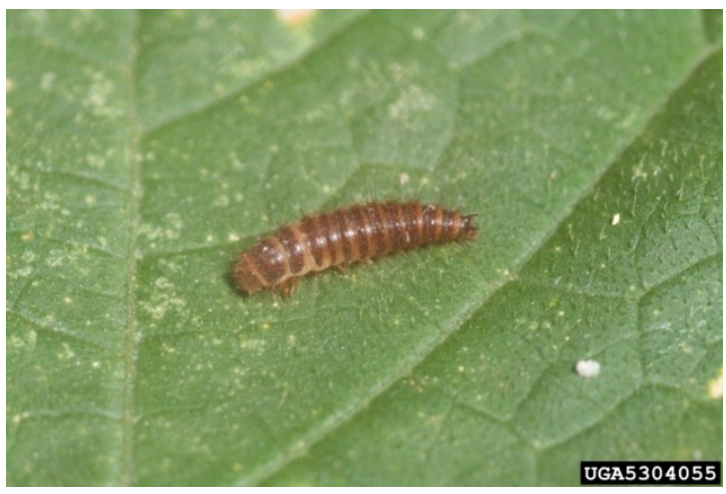

Hide beetle larva. Photo: Whitney Cranshaw, Colorado State University, Bugwood.org licensed under a Creative Commons Attribution 3.0 License.
Adults are 5.5 to $10 \mathrm{~mm}$ in size, and their elytra (hindwings) are brown or black with black, yellow, or white hairs. The underside of the beetle is white with black spots. Larvae are brown and covered with long hairs and have horn-like projections at the end of the abdomen.

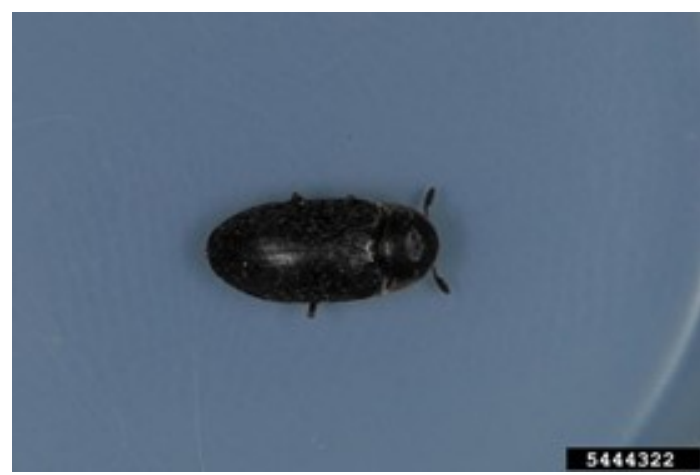

Hide beetle. Photo: Joseph LaForest, University of Georgia, Bugwood.org licensed under a Creative Commons Attribution-Noncommercial 3.0 License. 


\section{Dermestid Beetles}

Dermestid beetles feed on dried materials such as hair, meat, and skin. Common species include larder beetles, carpet beetles, skin beetles and hide beetles. For this manual, we will focus on hide beetles, some very common visitors to a body near the late stages of decomposition.

Hide beetles feed on the dry skin remains of corpses. Although adults may arrive earlier, larvae are found late in the decomposition process and are the life stage used to help with PMI. Dermestid beetle frass (feces) is especially helpful with PMI estimations and can even provide DNA and toxin information. This is because some flesh is enclosed in a casing (called a peritrophic membrane) that protects it from acid as it moves through the beetle's system, resulting in intact material that can be analyzed.

In addition, dermestid beetles are often used by museums to clean the bones of specimens.

Adults are 5.5 to $10 \mathrm{~mm}$ in size, and their elytra (hindwings) are brown or black with black, yellow, or white hairs. The underside of the beetle is white with black spots. Larvae are brown and covered with long hairs and have horn-like projections at the end of the abdomen.

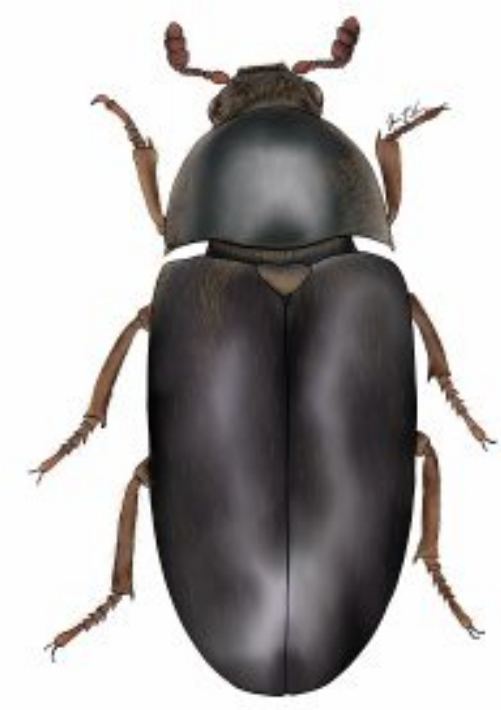

Dermestid beetle. Illustration: Justine LaViolette
Hister Beetle References:

Moore, M.R. \& Kaufman, P.E. "Featured Creatures: Hister Beetle." University of Florida. Retrieved from http://entnemdept.ufl.edu/creatures/beneficial/beetles/ Carcinops_pumilio.htm

Checkered Beetle References:

Australian Museum. 29 March 2019. "Corpse fauna. Many kinds of organisms live by feeding on dead bodies." Retrieved from https://australianmuseum.net.au/learn/science/ decomposition-corpse-fauna/.

MuseumPests.net (2015). "Red-legged Ham Beetle." Retrieved from https://museumpests.net/wp-content/uploads/2015/05/Fact-Sheet-Redlegged-HamBeetle.pdf

Rove Beetle References:

Department of Entomology Biological Control Information Center. "Rove Beetle."
North Carolina State University. Retrieved from http://www4.ncsu.edu/ dorr/Insects/ Predators/Rove\%20Beetles/rove_beetle.html

Mahr, S. "Rove Beetles." Master Gardener Program. University of Wisconsin Extension. Retrieved from https://wimastergardener.org/article/rove-beetlesstaphylinidae/

Carrion Beetle References:

Nebraska Game and Parks. "American Burying Beetle." Retrieved from http://outdoornebraska.gov/americanburyingbeetle/

Ratcliffe, B. C. (1996). "Carrion Beetles of Nebraska." Bulletin of the University of Nebraska State Museum. Volume 13

Dermestid Beetle References:

Shaver, b. \& Kaufman, P.E. "Featured Creatures: Hide Beetle." University of Florida. Retrieved from http://entnemdept.ufl.edu/creatures/misc/beetles/hide_beetle.htm 


\section{MISCELLANEOUS PREDATORY INSECTS}

\section{ANTS (FAMILY: FORMICIDAE)}

\section{Black Carpenter ant}

Black carpenter ants are the most common species of carpenter ant in NE. Adult workers are 6-12 mm, black with a rounded thorax, and feed on live and dead insects. Near a death scene, they've been observed on or near the body, crawling amongst the maggot mass and taking live maggots, or carrying dead flies away from the site.

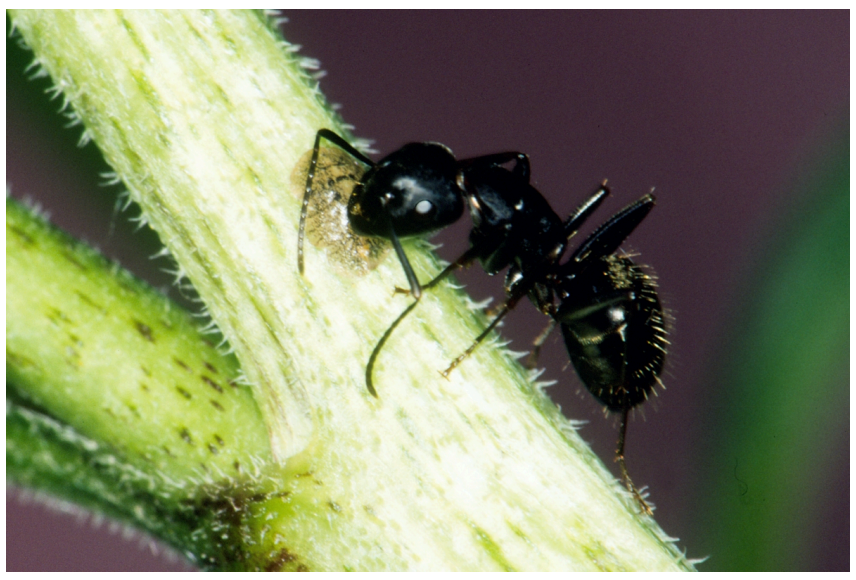

Carpenter ant. Photo: Jim Kalisch, UNL

\section{Ant References:}

Cochran, S. (2015). "Carpenter Ant Identification Resources." Nebraska Extension in Lancaster County. Retrieved from https://lancaster.unl.edu/pest/ants/cants.shtml

\section{EARWIGS (ORDER: DERMAPTERA)}

Earwigs look similar to rove beetles, except they have cerci, or "pinchers," at the ends of their abdomen. They are not beetles but are in the order Dermaptera. Coloration is usually brown to black, and they are around 5-25 mm long.

Earwigs are found in moist locations and will scavenge or predate on both plant and animal matter.

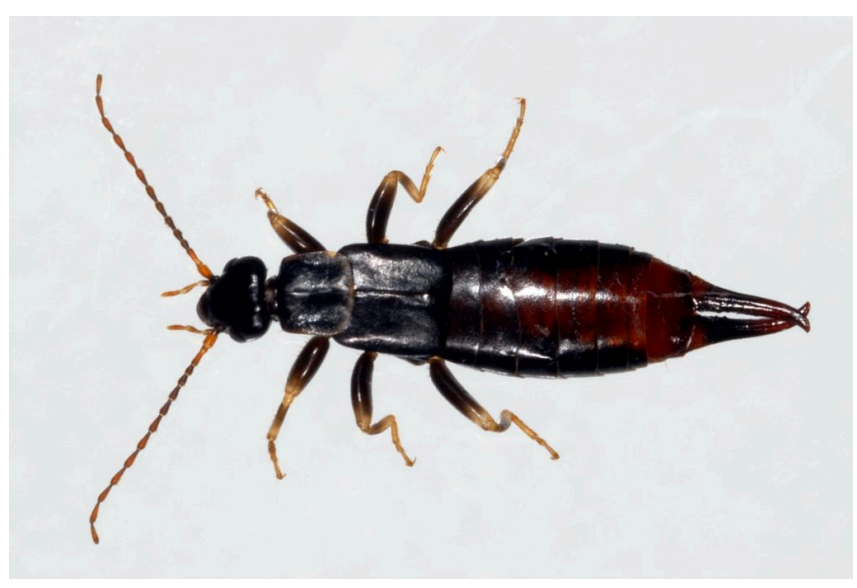

European earwig. Photo: Jim Kalisch, UNL

Earwig References:

Iowa State University Extension and Outreach. "Earwigs." Horticulture and Home Pest News. Retrieved from https://hortnews.extension.iastate.edu/earwig 


\section{OPPORTUNISTIC INSECTS}

\section{BUTTERFLIES (ORDER: LEPIDOPTERA)}

\section{Question mark butterfly (Family: Nymphalidae)}

Adult question mark butterflies have a bright orange inner wing color with a line of 4 darker spots near the upper edges of the top wings. The outside of the wings are brown and resemble a dead leaf, and they have a unique white/silver design that resembles a question mark. These butterflies feed on dung, fermenting fruit, sap, and other liquids and may be found at bodies drinking decomposition fluids.

Note: The comma butterfly looks very similar to the

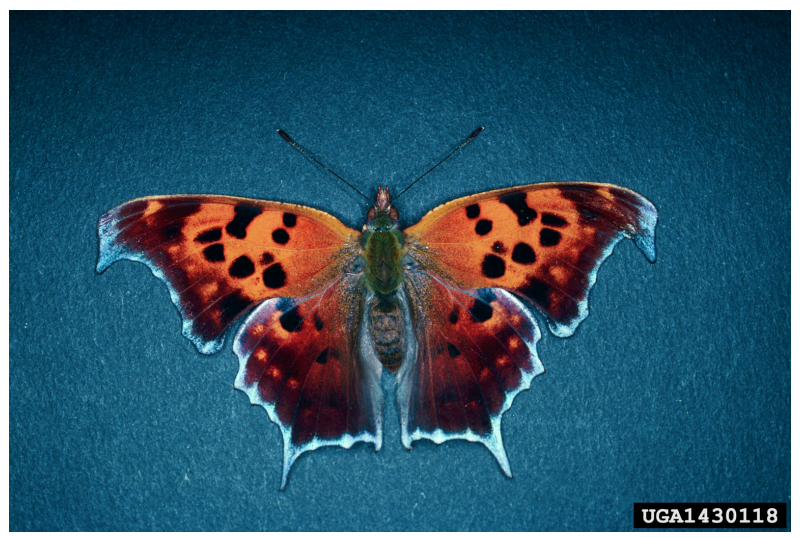

Question mark Butterfly: Lacy L. Hyche, Auburn University, Bugwood.org licensed under a Creative Commons Attribution 3.0 License.

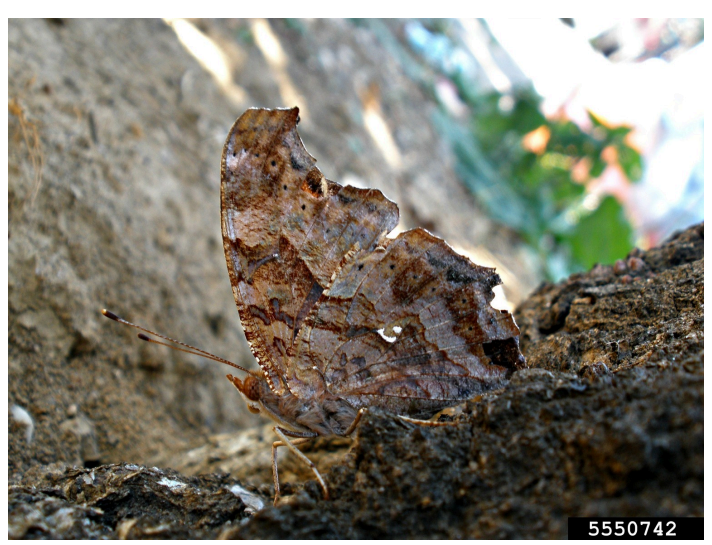

Question Mark Butterfly: Ansel Oommen, Bugwood.org licensed under a Creative Commons Attribution-Noncommercial 3.0 License. question mark butterfly. However, it has three black dots on its upper wings rather than four, and the white/silver mark on the underside of its wings is closed more like a comma, without the space found on the question mark butterfly. This butterfly feeds on sap, nectar, carrion, and dung and could also be potentially found at death scenes.

\section{References:}

Hall, D.W. "Featured Creatures: Question Mark". University of Florida. Retrieved from http://entnemdept.ufl.edu/creatures/bfly/bfly2/question_mark.htm

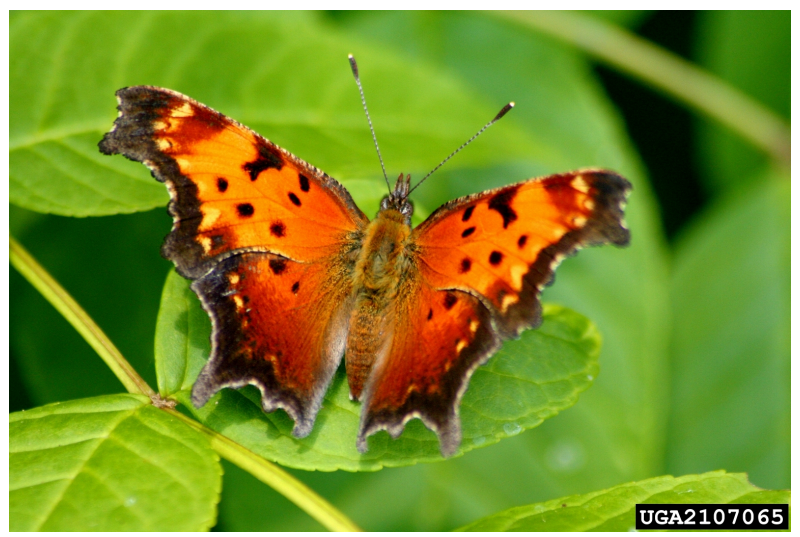

Comma Butterfly: David Cappaert, Bugwood.org licensed under a Creative Commons Attribution-Noncommercial 3.0 License.

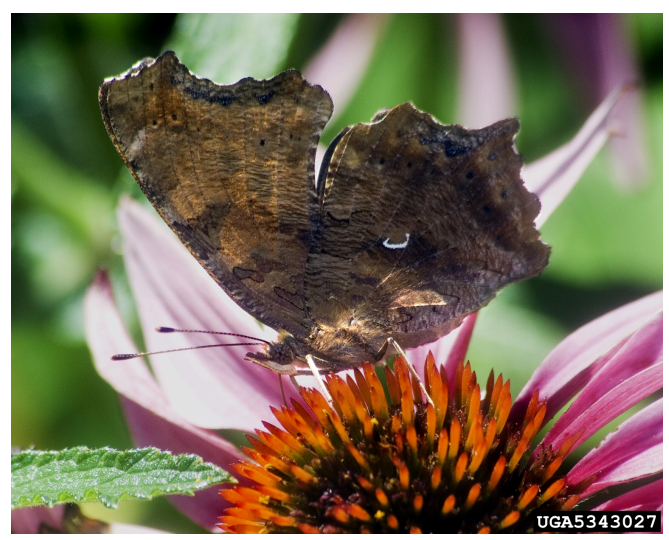

Comma Butterfly: David Cappaert, Bugwood.org licensed under a Creative Commons Attribution-Noncommercial 3.0 License. 


\section{BEES AND WASPS (ORDER: HYMENOPTERA)}

\section{Bumble Bees and Honey Bees}

Although it is not commonly known, honeybees and bumble bees have been seen feeding on carrion on multiple occasions. During the authors' research, different bumble bees were found feeding on the hanging carrion multiple times throughout the study (see image below). Bees usually feed on the decomposition fluids of the carrion, so it would be most likely to see them at a scene between the active decay and bloating stages.

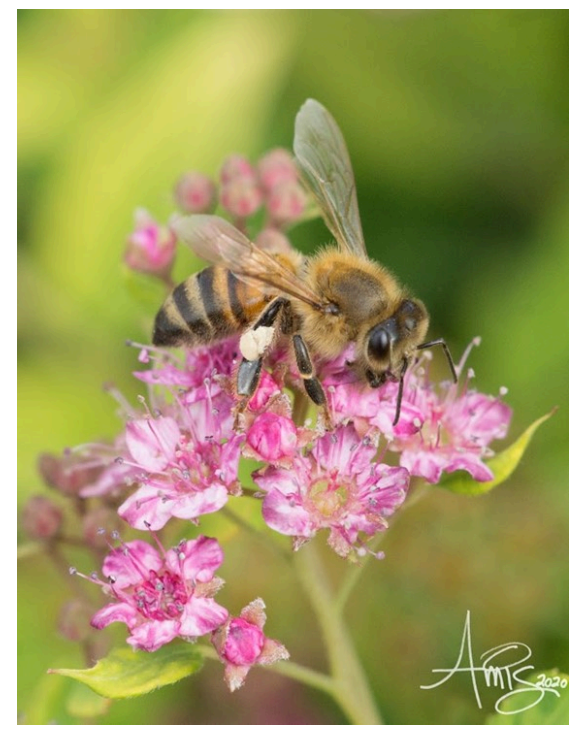

Honeybee Photo: Ami Sheffield

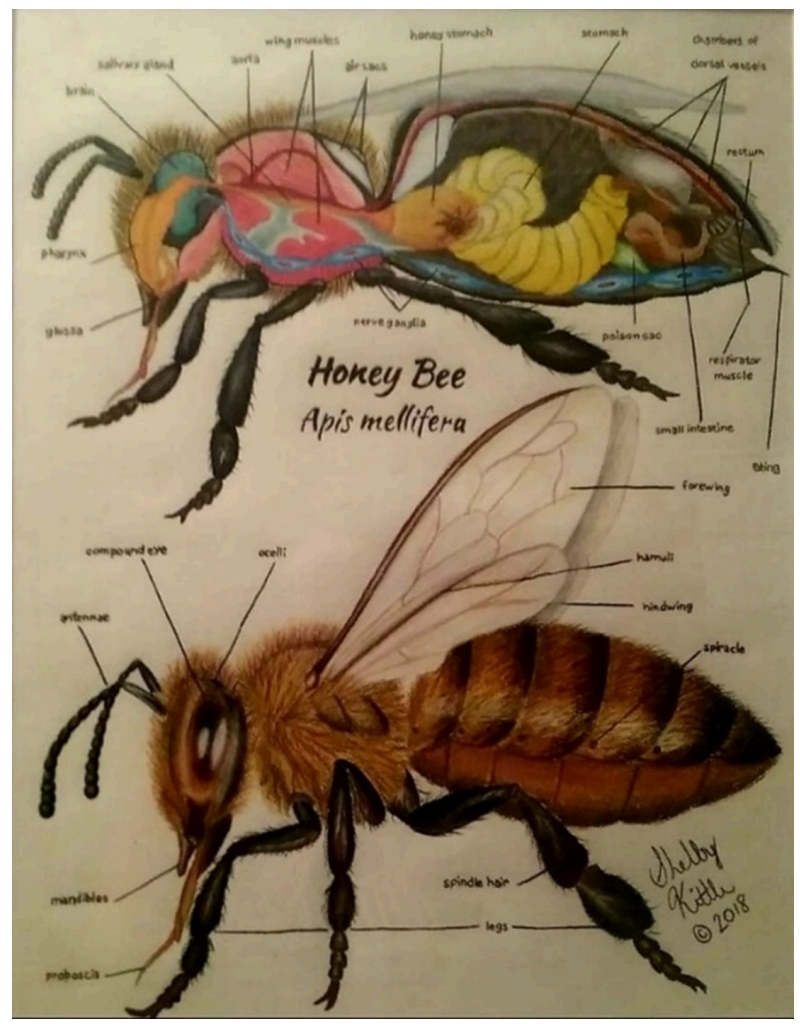

"A Bee's Anatomy" Illustration: Shelby Kittle,UNL

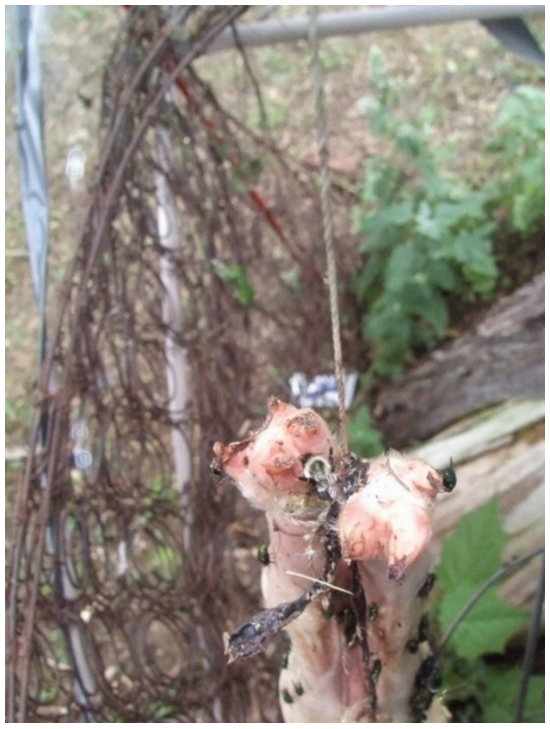

Bumble bee feeding on the decomposition fluids on the hanging carrion on Day three. Photo: Emma Sidel, UNL

\section{Thread-waisted wasps (Family: Sphecidae)}

Thread-waisted wasps in the family Sphecidae, such as mud daubers, are solitary wasps that hunt and collect live insects to stock in their nests for their larvae. They are usually $2.5 \mathrm{~cm}$ long or more. They can be black, bluish black, or have colors such as oranges and yellows combined with black. They can be identified by the stalk-like "waist" they have.

These wasps may be found near death scenes collecting maggots, flies, or other insects to take back to their nests.

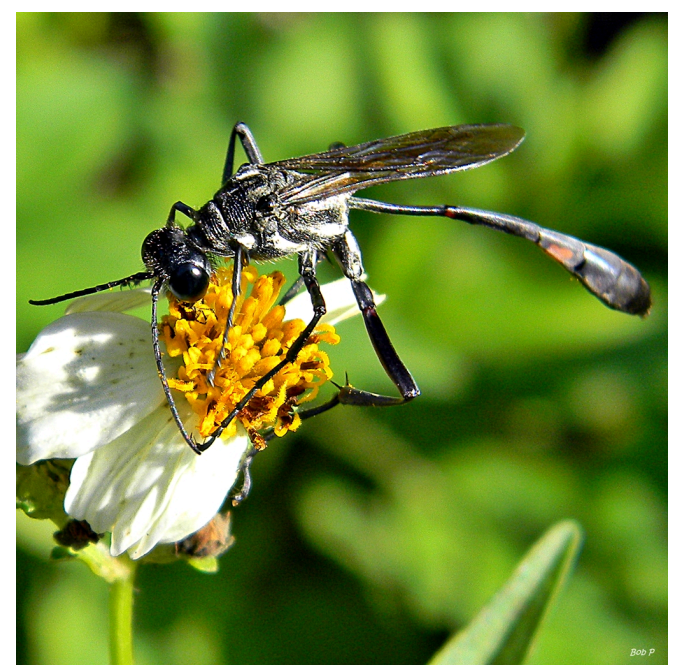

Thread-waisted wasp Photo: Bob Peterson Creative Commons Attribution-Share Alike 2.0 Generic

\section{Bee References:}

Ellis, Marion, Golick, Doug. 2011. EC00-1564 A Guide to Identifying Nebraska Bumble Bee Species. Retrieved from https://digitalcommons.unl.edu/ cgi/viewcontent.cgi? article $=3014 \&$ context $=$ extensionhist

Stejskal, Susan M. 27 August 2012. Death, Decomposition, and Detector Dogs: From Science to Scene (pg. 44). http://bit.ly/2slORSt

Thread Waisted Wasp References:

Encyclopedia Britannica. "Thread-waisted wasp." Retrieved from https://www.britannica.com/animal/thread-waisted-wasp 

PART III.

CASE STUDIES 



\section{CASE STUDY 1}

This field exercise examines a pig research study conducted between June 25, 2018 and July 3, 2018.

For this study, a small rectangular location was set up on the northeast corner of the University of Nebraska-Lincoln Forensics study grounds. A barrier of tires was used to block off the location. The subject, a $17 \mathrm{lb}$. female deceased American Landrace piglet, was placed on the ground within the location and surrounded with wire secured by stakes to discourage predatory movement (i.e., mammalian or avian scavengers pulling or feeding on the carcass). The piglet was then observed for 9 days for insect activity during various stages of decomposition (with some post-research visits). The site was visited between 2:00 and 2:30 p.m. every afternoon to keep a consistent time frame.

In general, the researchers anticipated seeing blow flies as the first visitors, followed by other types of flies, beetles, and predatory insects. Some opportunistic insects also visited the body to feed (i.e., butterflies feeding on body fluids).

Blow fly maggots feed on dead tissue, and their lifecycle includes three larval instars, a pupa, and the adult. The third instar migrates away from the body to find a place to pupate.
The researchers expected to see this behavior during the study. Below are a few highlights from the study, demonstrating what was done during each visit and what was collected.

Photos and videos of insect activity and decomposition (from camera, cell phone, and including standard and infrared) were taken each day at the scene.

Case Study 1, 2018: Temperature and Weather Chart
\begin{tabular}{|c|c|l|}
\hline Day & $\begin{array}{c}\text { Temperature } \\
\left({ }^{\circ} \mathrm{F}\right)\end{array}$ & Weather Conditions \\
\hline 1 & 74 & Rainy and cloudy \\
\hline 2 & 83 & Sunny, but rained previous night \\
\hline 3 & 86 & Sunny \\
\hline 4 & 89 & Sunny, hot, and humid \\
\hline 5 & 95 & Sunny, hot, and humid \\
\hline 8 & 87 & Sunny and humid \\
\hline
\end{tabular}

\section{DAY 1: JUNE 25, 2018, FRESH STAGE}

The weather was rainy and cloudy, and the temperature was $74^{\circ} \mathrm{F}$. The newly deceased female piglet (research subject) was picked up from the University of Nebraska-Lincoln Animal Science department and taken to the forensic study grounds. She was placed in a chosen location of the northeast corner of the grounds. Wire mesh was placed around the subject to keep predators from carrying her away (Figure 1).

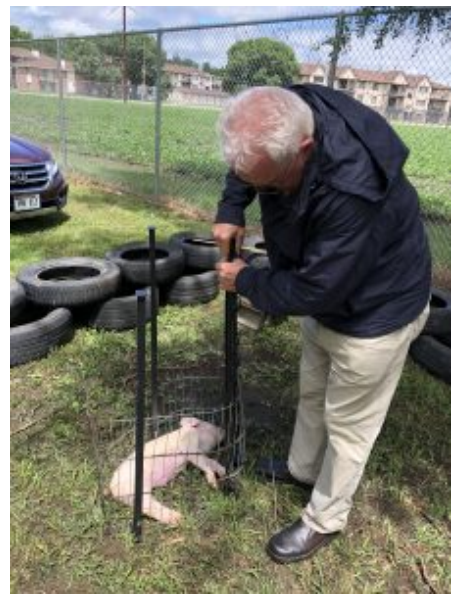

Figure 1: Wire mesh placed around piglet, Erin Bauer, UNL

\section{Observations and Actions:}

- Both blow flies (Figure 2) and flesh flies appeared almost instantly. They were seen around natural openings such as the nose, ears, and anus as well as the hooves and side. Specimens of both types of flies were collected and later pinned.

- It had been raining most of the day and had stopped before the researchers arrived at the study area. It was still cloudy upon arrival, but by the end of the study period, the sun had come out.

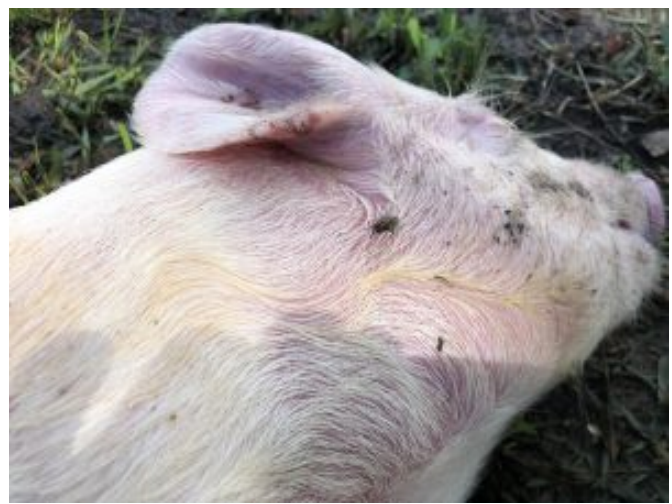

Figure 2: Blow fly on piglet, Erin Bauer, UNL 
The weather was sunny with a temperature of $83^{\circ} \mathrm{F}$. However, it had rained all night. The piglet looked as fresh as on Day 1, but there were significantly more flies.

\section{Observations and Actions:}

- Flies were found mostly around natural openings: mouth, anus, and in the nose (Figure 3). Primarily green bottle flies (identified post collection) were around the body. There were no signs of maggots yet, but female flies were observed laying eggs (Figure 4). Also, there were yellow areas under the chin that were likely egg masses. Around the hole where the animal's ear tag had been removed, there was not a lot of activity yet.

- Other types of arthropods were also seen, including predators such as small black ants, smaller red ants, earwigs, small flies ("gnats"), and incidentals, such as sowbugs, that live in the surrounding environment. A carpenter ant was collected and later pinned.

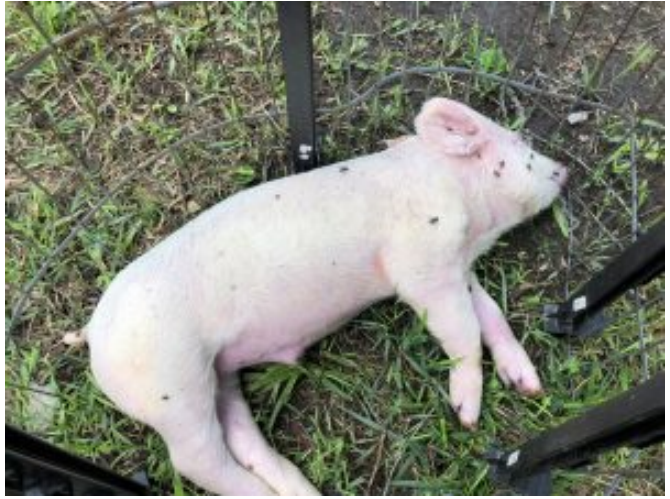

Figure 3: A lot of fly activity near natural openings

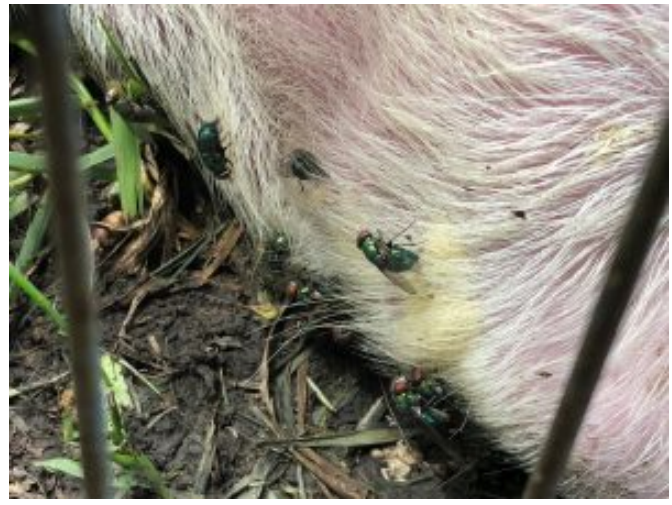

Figure 4: Blowflies laying eggs, Erin Bauer, UNL

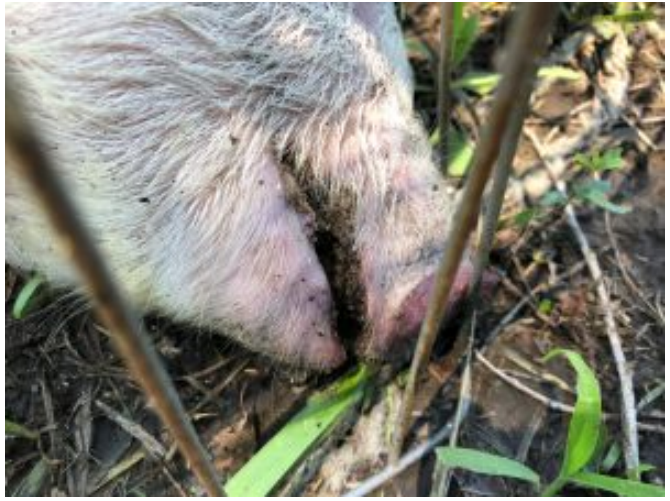

Figure 5: Maggots in mouth, Erin Bauer, UNL

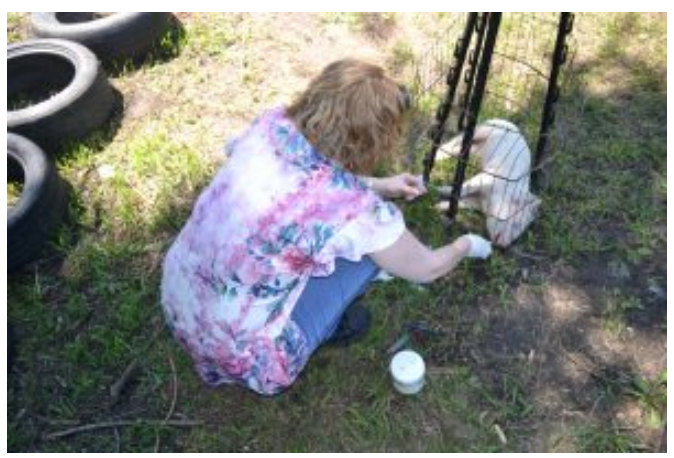

Figure 6: Collecting first instar maggots, Larry Barksdale, UNL 
DAY 4: JUNE 28, 2018, BLOATED STAGE

The weather was sunny, hot, and humid at $89^{\circ} \mathrm{F}$. Photos and videos were taken at the scene.

\section{Observations and Actions:}

- It was observed that a predator attacked the pig overnight. The front of her face/snout was gone, and the researchers saw a large maggot mass within the mouth area (Figure 7). The maggots mostly appeared to be second and third instars. Maggots were collected from this area and preserved. One of the pig's teeth was moving due to the pressure of the maggot mass. The subject was more bloated (Figure 8).

- Many blow flies were present compared to the past three days. They were especially concentrated in the removed tag hole near the ear and in the chest, eyes, and mouth. Many blow flies were still laying eggs on the chest and neck and in the hole near the ear. Some were still interested in the mouth region. There were a few new (likely first instar) maggots in the anal area. An area of the chest had significant maggot activity right underneath the skin.

- Ant predators were seen among the maggots. Also, a carpenter ant was seen carrying away a dead green bottle fly. There were many carpenter ants near the body, but no beetles were seen.

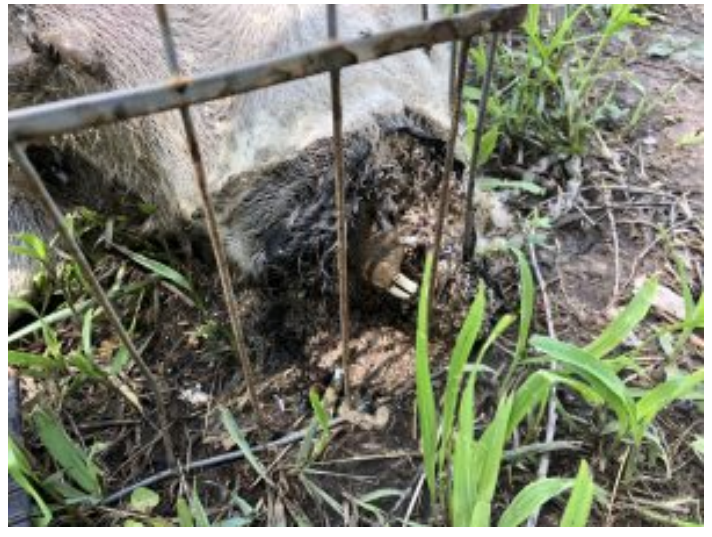

Figure 7: Maggot mass in pig mouth, Erin Bauer, UNL

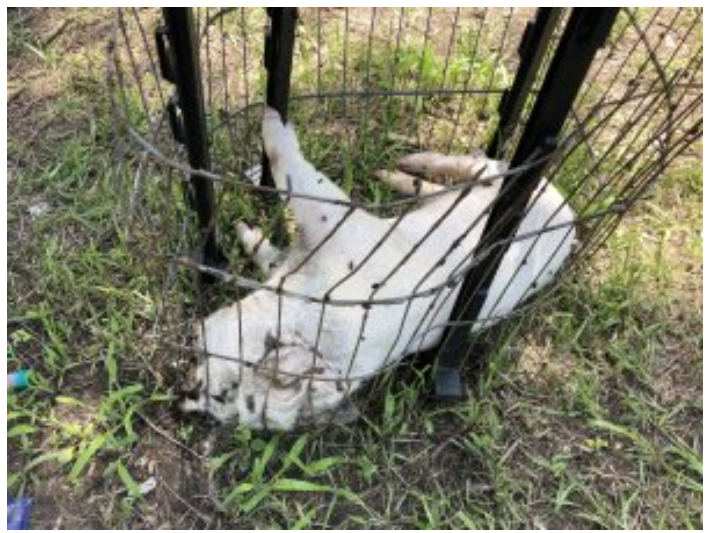

Figure 8: Bloating and lots of fly activity, Erin Bauer, UNL

- A few other miscellaneous insects were seen, such as beetles (i.e., hairy rove beetle) and ants.

- Migrating maggots were going quite a distance to pupate (Figure 10). One went 15 inches from the body into a crack in the ground. Another went about 24 inches from the body.

- The researchers brought out the HOBO Data Logger, which is a temperature and humidity reader, and a thermometer to measure temperature of maggot masses. Results from using a probe thermometer were as follows:

- The maggot mass in the chest had a temperature of $98^{\circ} \mathrm{F}$ (between the front legs); the maggot mass between the back legs was $92^{\circ} \mathrm{F}$. Down on the ground under the rear legs was $86^{\circ} \mathrm{F}$.

- Inside the mouth, deep into the throat and brain cavity was $104 / 105^{\circ} \mathrm{F}$. Inside the hole in the ear was $106^{\circ} \mathrm{F}$. 


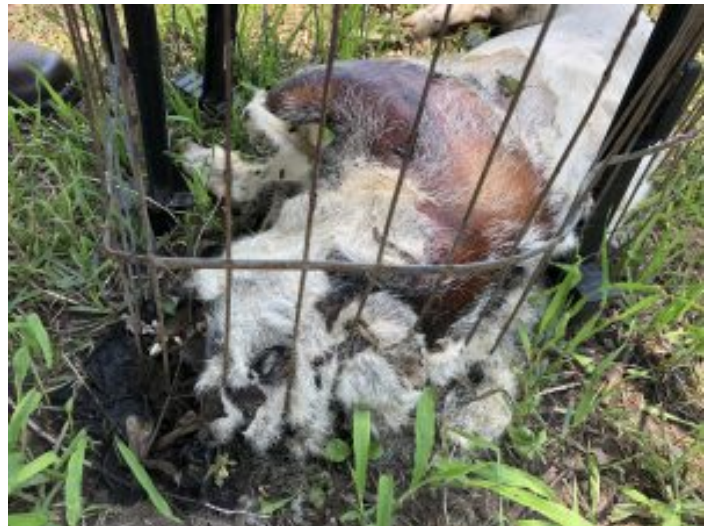

Figure 9: Looking more mummified, Erin Bauer, UNL

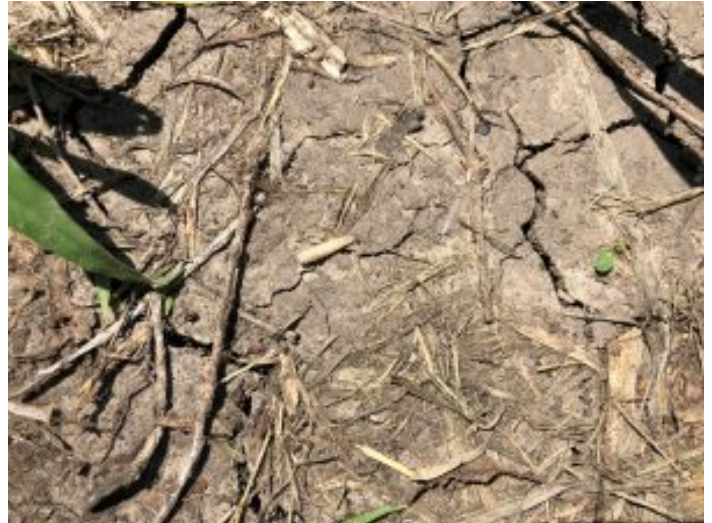

Figure 10: Migrating maggot, Erin Bauer, UNL

See the following image for information on the environmental temperature and humidity as measured and recorded by the HOBO instrumentation (Figure 11). See Processing the Death Scene Step-by-Step, "Scout the Scene" section of this manual for more information.

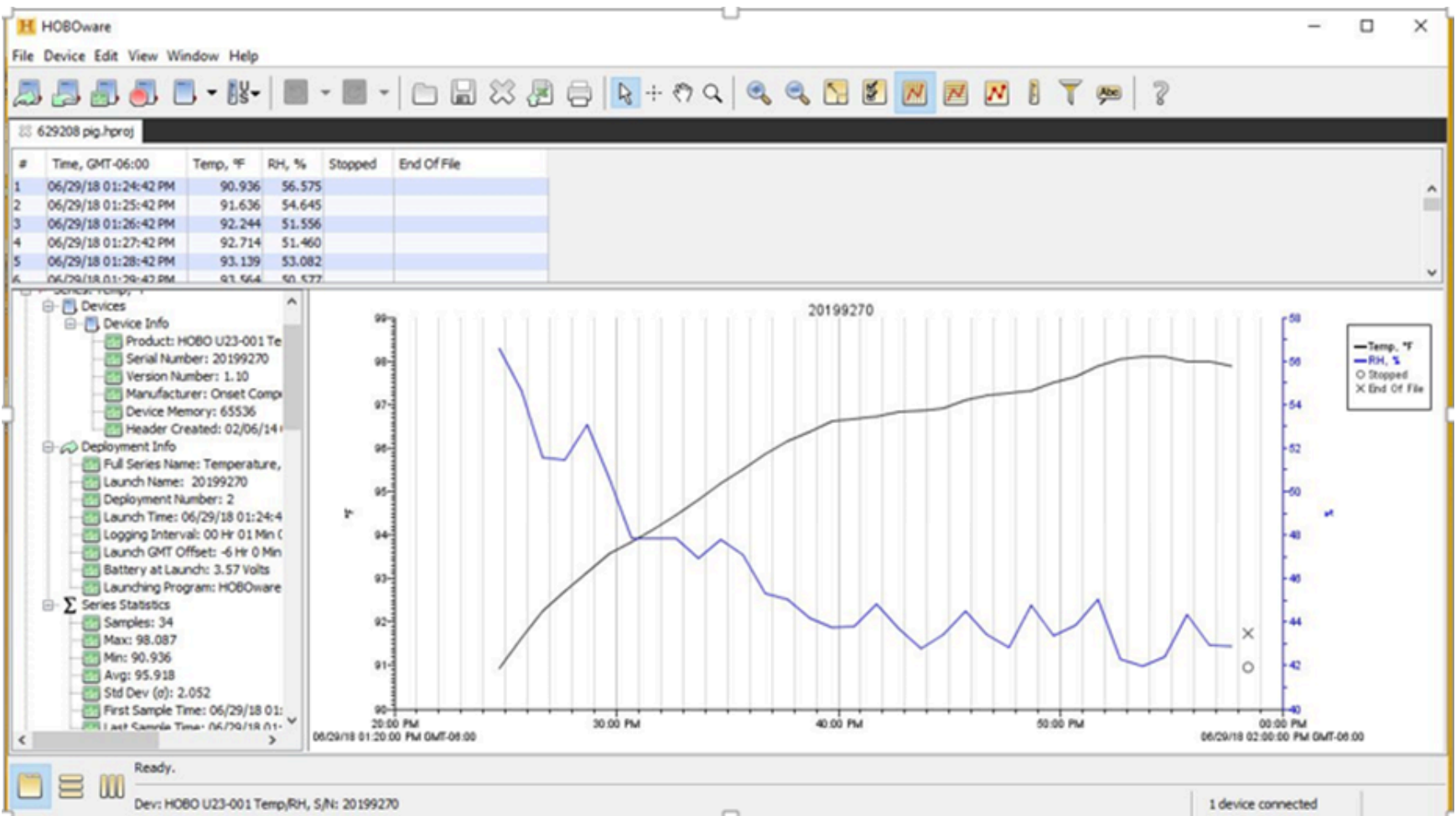

Figure 11: Example of HOBO data

\section{DAY 8: JULY 2, 2018, POST DECAY STAGE}

The weather was sunny, humid, and $87^{\circ} \mathrm{F}$. The piglet at this point was unrecognizable. The body was really deflated; there was no longer any tissue mass, just some skin, hide and bones remained (Figure 12). Remains were drying out.

\section{Observations and Actions:}

- Around the body were predatory beetles such as rove beetles, hister beetles, and others. Surprisingly, no carrion beetles were spotted during the study. Ants, small "gnat-like" flies, rove beetles, and a stray fly or two were still seen. A predatory wasp was seen in the area trying to pick up maggots to bring back to her nest. Many of these insects were collected and pinned (see the Forensic Insects Descriptions section in this publication for more information and photos).

- Third instar maggots were moving en-masse! This extensive migration was up to 10 feet with a large mass around a tire (5-foot migration; Figure 13). Migration was occurring around all sides of the body. Some of the migrating maggots were collected and preserved. 


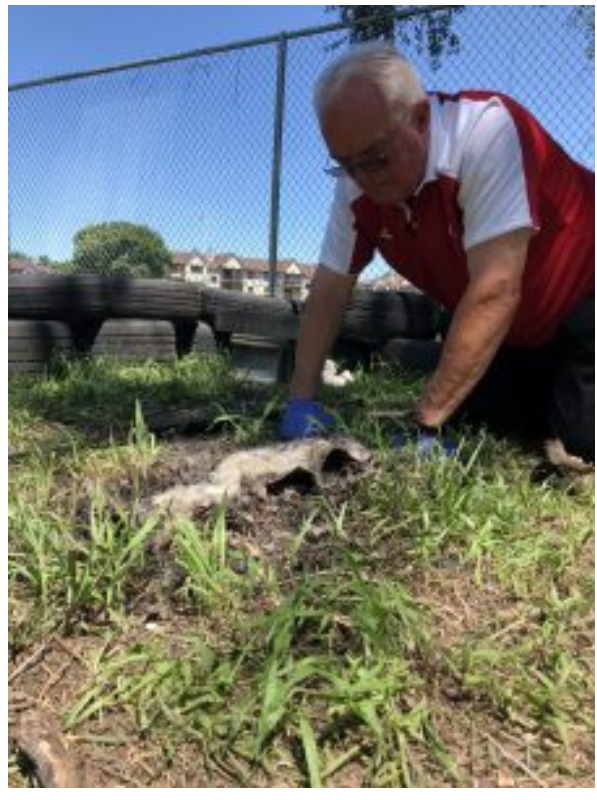

Figure 12: Pig down to hide and bones, Erin Bauer, UNL

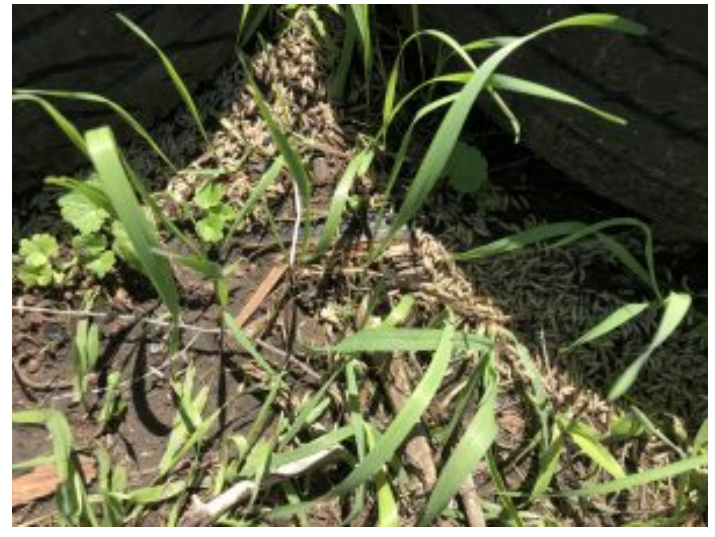

Figure 13: Maggot mass by tires, Erin Bauer, UNL

\section{DAY 9 AND BEYOND, POST DECAY AND SKELETAL STAGE}

Once the piglet reached late decomposition, the researchers did not check on it daily, but visits were more spread out. Observations made after Day 8 were that maggots disappeared and only hide and bones remained. At one point, the hide showed a white substance that the researchers suspected was adipocere or corpse wax (a waxy substance created in fatty tissues of a dead body by anaerobic bacteria). Dead dermestid beetles were also found near or on the hide. Although adults may be found earlier in the process, larvae feed on the dry hide. The beetles found may have been hatched adults or could have been there laying eggs.

Later, large animal predators carried the hide away, and at that point, only bones were left at the site. 


\section{CASE STUDY 2}

This field exercise was a pig research study conducted between July 2 and Aug 2, 2019 at the UNL Forensics study grounds. We did not take exact air temperature each day but instead recorded a range. In this trial, the researchers observed decomposition rates and insect succession in eight different scenarios that represented potential real-life crime scene situations.

Eight deceased piglet runts, all under $10 \mathrm{lbs}$, were placed in the following simulated scenarios:

1. Control; set in mowed open area.

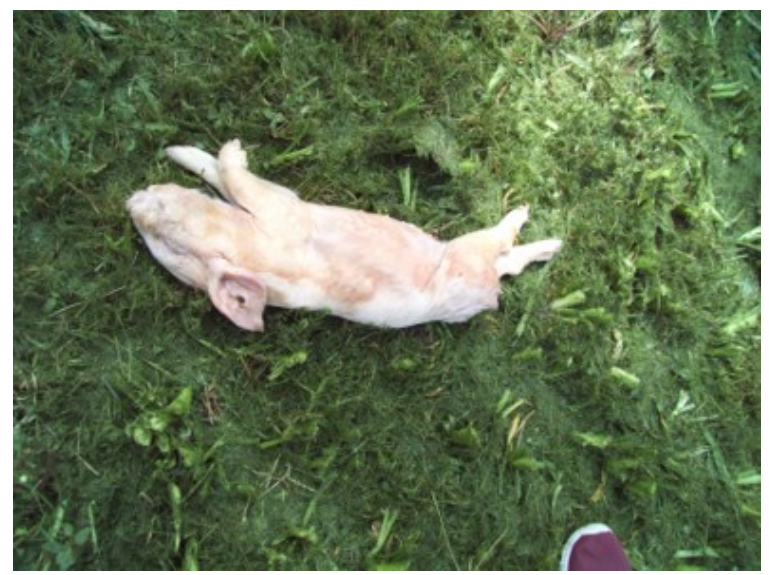

Figure 14: Control Pig on Day 1. Photo: Emma Sidel, UNL

2. Clothed; dressed in a child's lavender hooded sweatshirt.

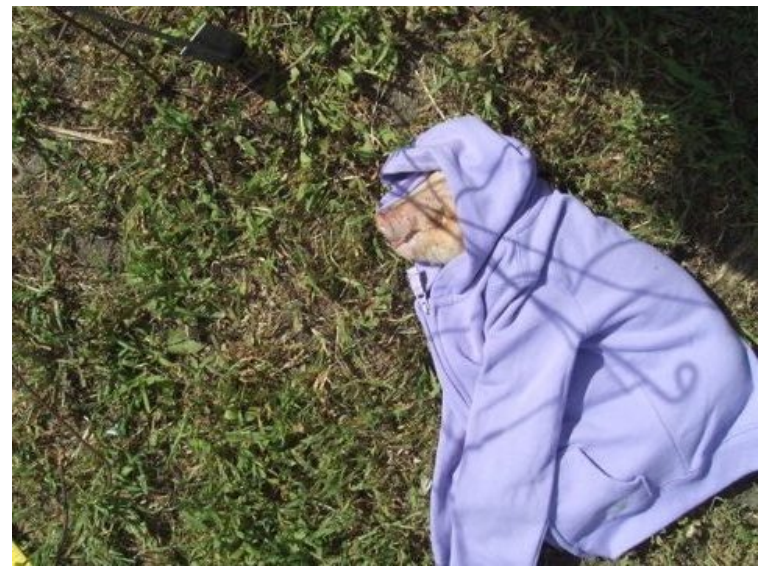

Figure 15: Clothed pig on Day 1. Photos: Emma Sidel, UNL
3. Hanging; back feet hung by string on a tree branch in a shady area.

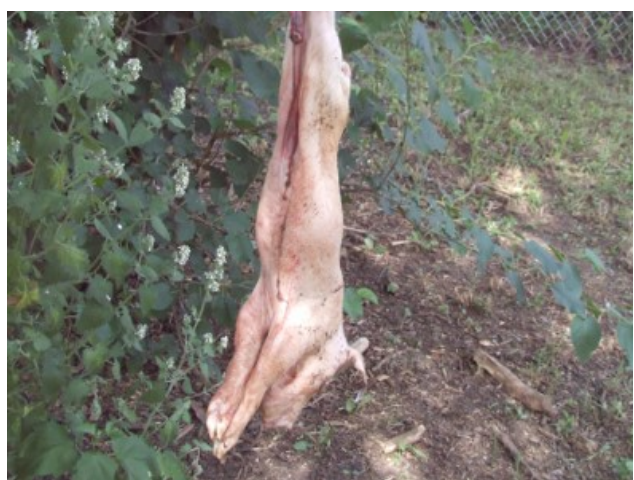

Figure 16: Hanging pig on Day 1 Photo: Emma Sidel, UNL

4. Trunk; placed inside an enclosed car trunk, which was warped and had gaps.

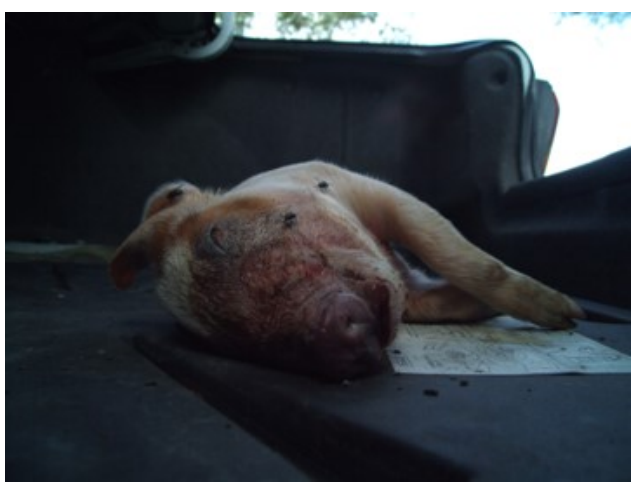

Figure 17: Trunk pig on Day 1. Photo: Emma Sidel, UNL

5. Buried in a shallow grave.

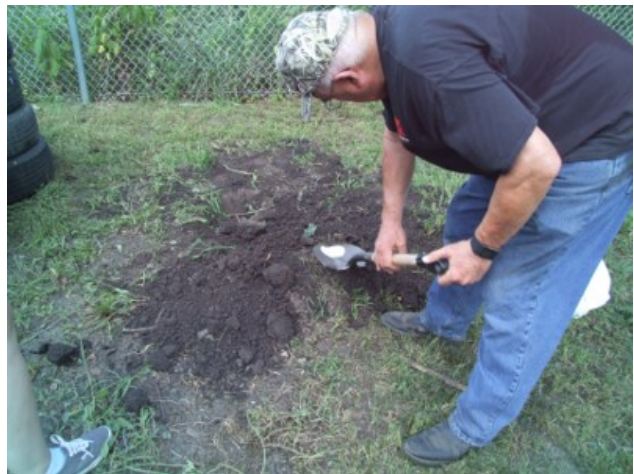

Figure 18: Buried pig on Day 1. Photo: Emma Sidel, UNL 
6. Cistern; put in bottom of old child's swimming pool, filled with soil and trash; damper environment.

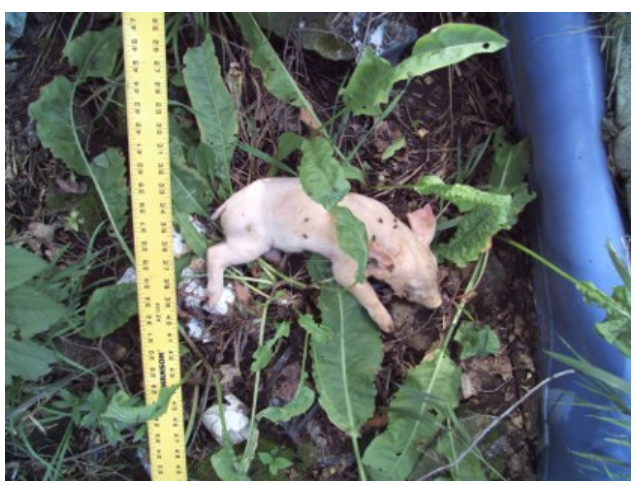

Figure 19: Cistern pig on Day 1. Photo: Emma Sidel, UNL

7. Trash bag; wrapped in plastic and put in a weedy area.

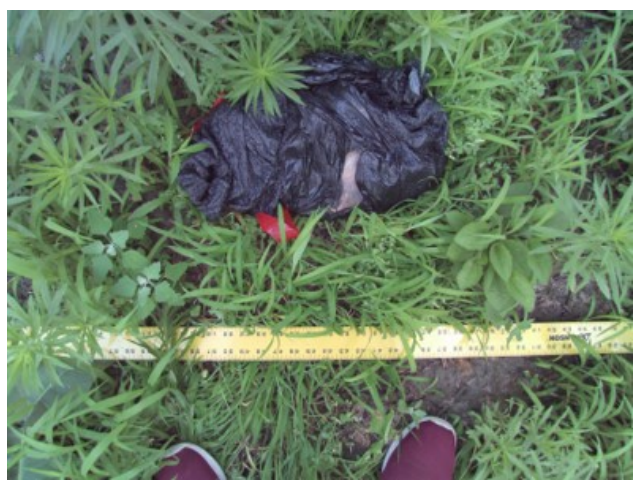

Figure 20: Trash bag pig on Day 1. Photo: Emma Sidel, UNL
8. Trauma; hit postmortem with a baseball bat, primarily on the head and some near the ribcage, and then placed in an enclosure made of used car tires.

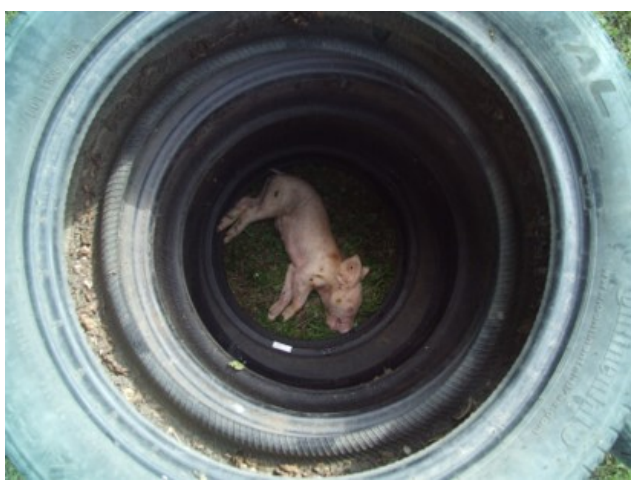

Figure 21: Trauma pig on Day 1. Photo: Emma Sidel, UNL

Case Study 2, 2019: Temperature and Weather Chart

\begin{tabular}{|c|l|l|}
\hline Day & $\begin{array}{l}\text { Temperature } \\
\text { F) }\end{array}$ & $\begin{array}{l}\text { Weather } \\
\text { Conditions }\end{array}$ \\
\hline 1 & $\begin{array}{l}\text { Upper 80's, } \\
\text { lower 90's }\end{array}$ & \\
\hline 2 & 90 's & Sunny \\
\hline 3 & Low to mid 80's & Cloudy and rainy \\
\hline 4 & 70 's & Rainy \\
\hline 5 & $70 ' s$ & Cloudy \\
\hline 6 & 70 's & Sunny \\
\hline 8 & 80 's & Sunny \\
\hline 32 & Mid 70's & \\
\hline
\end{tabular}

\section{DAY 1, JULY 2, 2019, FRESH STAGE}

The weather was in the upper 80s to lower 90s for most of the day and sunny. At 3:30 p.m., the eight pigs were placed on site at the UNL Forensics property in their individual scenarios. All pigs, other than the buried pig and the one in the closed vehicle trunk were surrounded by either wire mesh or, in the case of the traumatized pig, by a stack of 4 tires to discourage predator activity. During the initial setup, photos and video was taken, as well as scale measurements. Environmental insects such as earwigs and bumblebees (disturbed while digging the shallow grave) were collected, as well as the blow flies and flesh flies visiting the corpses. Photos and videos were also taken throughout the study.

\section{Observations and Actions:}

- Blow flies and flesh flies arrived within minutes after the pigs were placed. The hanging pig especially seemed to attract a large number, but the car trunk, cistern, and control pigs also had flies. The clothed pig was completely covered by the child's sweatshirt except for the face. While there were flies that crawled on the face, it still had fewer than the others. The site of the buried pig showed no immediate insect activity after being covered with dirt, and while the trash bag wrapped pig was attracting flies, the restricted access likely factored into how quickly they could colonize. The traumatized pig had a few flies, and where it was struck postmortem with the bat attracted more flies than the rest of the body.

- On Day 1, several blow flies, a flesh fly, a bumble bee, and two earwigs were collected. Blow fly eggs were also collected from the pig in the trunk and the hanging pig.

\section{DAY 2, JULY 3, 2019, FRESH AND BLOATED STAGE}

The weather was in the 90's and sunny. The team went out to the property at 11:30 a.m.

\section{Observations and Actions:}

- During this visit, it was observed that the hanging pig 
had large numbers of blow flies, including females that were ovipositing. Many eggs were laid between the back legs, face, and the umbilical cord, with the largest mass being between the front legs (Figure 22).

- The car trunk pig and trauma pig also had egg masses. The trunk pig had them on the face and was already in the bloat stage. The trunk pig was the only one of the corpses to currently be in this bloated stage, likely due to the heat in the trunk. Blow flies were all over the body. The traumatized pig had a fly egg mass near the face, likely due to the trauma areas as well as the natural orifices.

- The cistern pig had some fly activity, while the control and clothed pig did not have much, and the buried pig did not have any visible insect activity.

- Within the trash bag, it appeared that flies had now gained access and were likely laying eggs.

- On Day 2, several blow flies were collected as well as a wooly bear caterpillar.

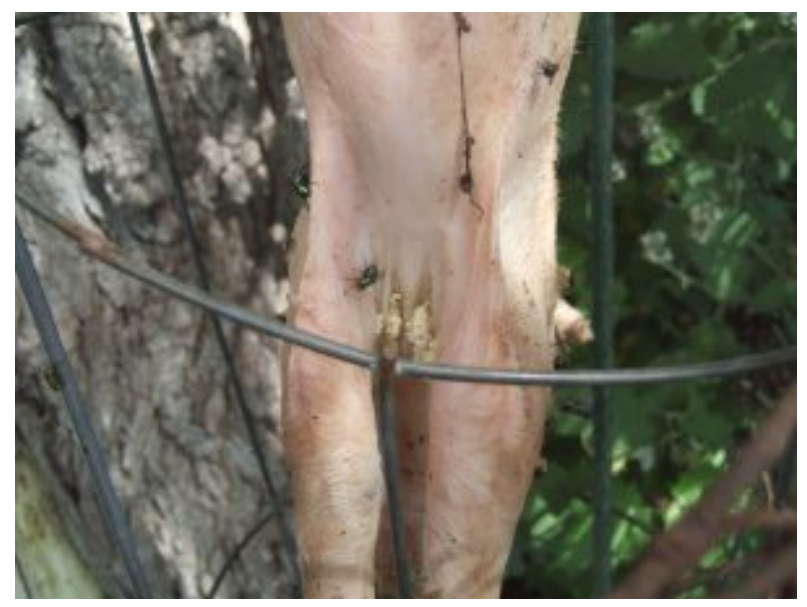

Figure 22: Egg mass between front legs of hanging pig on Day 2. Photo: Emma Sidel, UNL

\section{DAY 3, JULY 4, 2019, BLOATED STAGE}

The weather was in the mid to low 80s, cloudy and rainy. Researchers visited at 8:30 a.m. During this day, there were still many blow flies observed as well as many flesh flies.

\section{Observations and Actions:}

- The control pig now had very active first instar larvae in its mouth. The hanging pig also had first instar larvae starting to hatch from the anus area as well as bumblebees feeding from decomposing body fluids. There was also skin slippage apparent near the ears and back of the head.

- More flies were seen around the cistern pig, but the largest number of flies were around the hanging and trunk pig.

- The pig in the trunk had more pronounced bloating, with blow flies and flesh flies on the body and eggs laid on the face with no visible maggots. A carpenter ant was also seen in the trunk.

- The clothed pig had a few flies around the face but otherwise no extensive activity.

- The traumatized pig's snout/mouth was eaten away and decomposing more quickly than the rest of the body with first and second instar larvae evident (Figure 23). There were still numerous flies as well as a cricket seen around the tires. The body had lots of mottling (colored blotches on skin) and was very odorous.
- The trash bag pig now had more blow flies inside the bag, with flesh flies, blow flies, and tiny ants crawling on the outside.

- On Day 3, several blow flies, a flesh fly, and a bumble bee were collected. Some first and second instar maggots were collected from the mouth of the traumatized pig and the control pig.

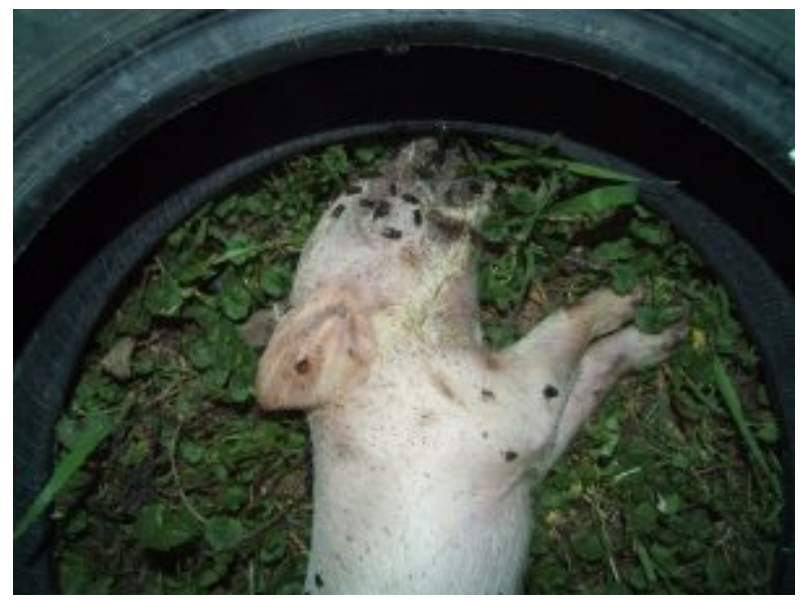

Figure 23: Traumatized pig shows maggot activity in the front of the face, one of the places subject to blunt force trauma postmortem. Photo: Emma Sidel, UNL

\section{DAY 4, JULY 5, 2019, ACTIVE DECAY STAGE}

The weather was in the 70's and rainy, and the team visited at 8:30 a.m. This was a day of significant change in the pigs. There was extensive decomposition and maggot activity since the day before. This may have been due to temperature changes and humidity level fluctuations.

\section{Observations and Actions:}

- Notably, like in the 2018 study, there did not appear to be any carrion beetle activity. It is unclear what factors have contributed to it, but some possibilities include temperature and humidity, location, observation times (some beetles may be more active at night or different 
times of the day), or the time of year.

- There were significant changes in the control and cistern pigs. With the control pig, the whole face and other parts of the body were crawling with maggots, and the ribs were showing unlike the previous day where the body was bloated with maggots only in the mouth (Figure 24). Similarly, the cistern pig looked intact yesterday, while today almost the entire body was crawling with maggots (Figure 25). Because of these changes, it looked like the control and cistern pigs would be the first to completely decompose, which is different than earlier hypotheses that the car trunk pig, due to the heat of an enclosed trunk, the traumatized pig, due to injuries, and the hanging pig, due to extensive fly activity, would be faster decomposers.

- With the trunk pig, it appeared to still be bloated, and had adipocere (decomposition wax) on its back-right side. Maggots had now hatched and were all over the face, body, and underneath the body in the trunk (Figure 26). First and second instars were apparent, and there were still many flies.

- The hanging pig had many flies, and maggots falling off and crawling on the ground underneath the body.

- The pig in the trash bag now had numerous hatched maggots crawling outside of the bag.

- The clothed pig still did not show excessive activity, although there were flies around the head.

- The trauma pig's face was mostly gone, but not as much of the body was affected yet. This is likely due to the postmortem damage applied to the head and demonstrates how blunt force trauma can be inferred from observed insect activity according to location and extent of maggot activity.

- On Day 4, second and third instar maggots were collected from the control, hanging, trunk, tire trauma, trash bag, and cistern pigs.

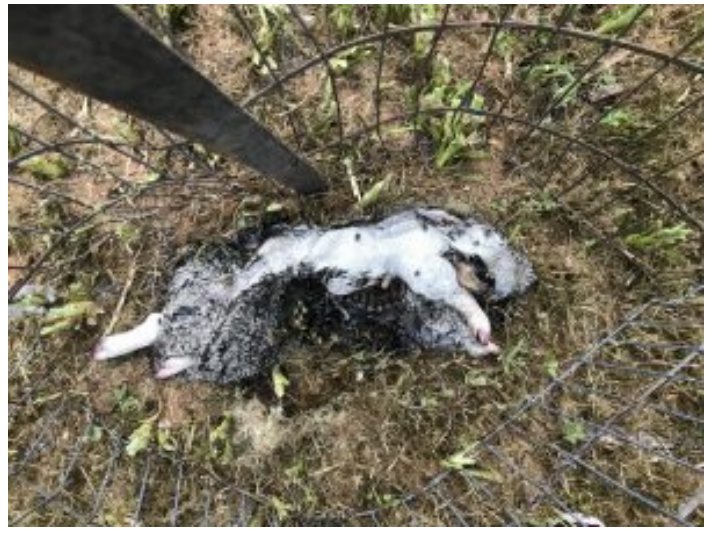

Figure 24: Control pig Day 4. Photo: Emma Sidel, UNL

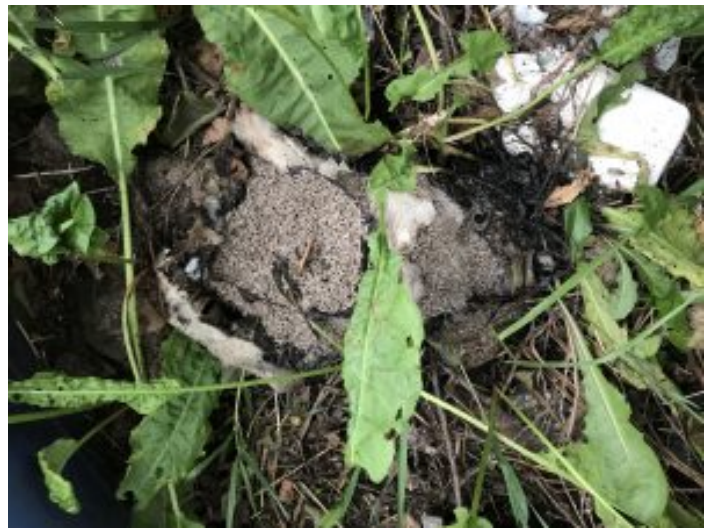

Figure 25: Cistern pig. Photo: Emma Sidel, UNL

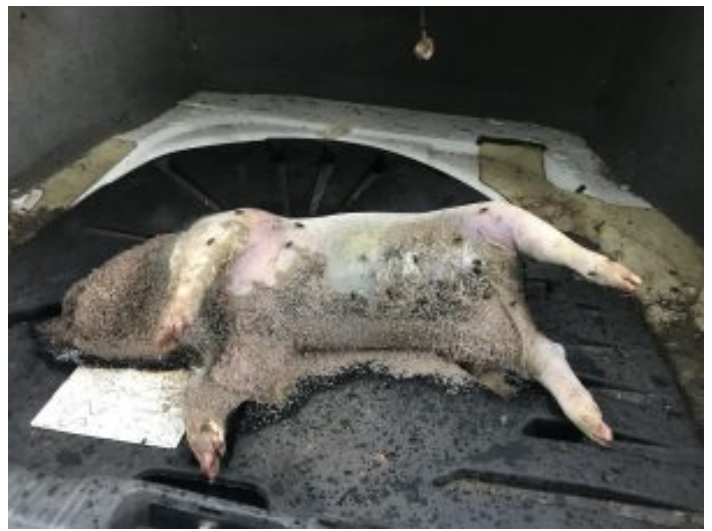

Figure 26: Trunk pig Day 4; bloating and maggots. Photo: Emma Sidel, UNL

\section{DAY 5, JULY 6, 2019, ACTIVE DECAY STAGE}

This was the second day where extreme change in the pig subjects was observed. The temperature was in the 70's and cloudy, and the team visited at 8:30 a.m.

\section{Observations and Actions:}

- The control pig was almost completely decomposed from head to toe with several maggots still present (Figure 27). A large rove beetle was found crawling around on the remains. Similarly, the cistern pig had active decay, with the flesh nearly gone. It, however, had fewer maggots than were seen yesterday.

- The pig in the trunk looked like a sheep...maggots were completely covering it from head to toe, with the head almost completely decomposed (Figure 28). All stages of maggots, including third instars that looked ready to migrate, were present. Some blow flies were also still present, as well as predators such as an ant and rove beetle. The temperature of the maggot mass was recorded at 103 degrees Fahrenheit.

- The traumatized pig's head was gone, with the maggot 
mass now concentrated on the rear of the animal.

- The clothed pig's sweatshirt was now dirty due to decomposing fluids and the environment, and the body was noticeably "shrunken" underneath the clothes. The pig's head was more decomposed than on the previous day.

- The trash bag pig was full of maggots, inside and out, in several spots.

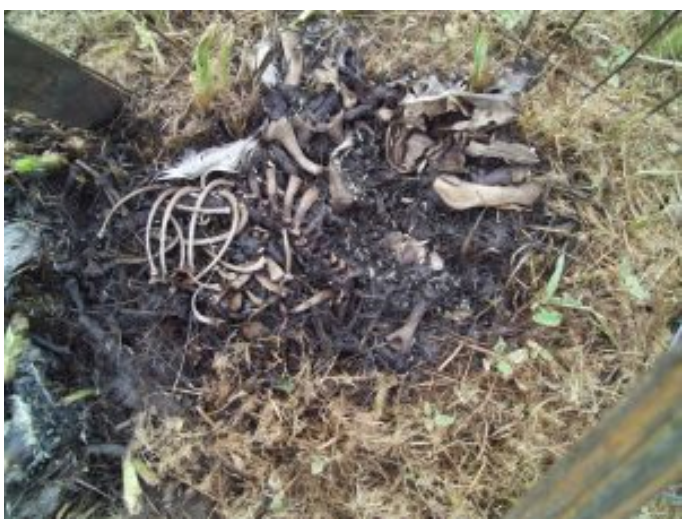

Figure 27: Control pig on Day 5. Photo: Emma Sidel, UNL
- The hanging pig looked like skin as the bones and had fallen practically to ground. There were still many blow flies and a few maggots on the body. Bumblebees were seen drinking again.

- On Day 5, second and third instar maggots were collected from from the trunk, trash bag, and tire trauma pigs.

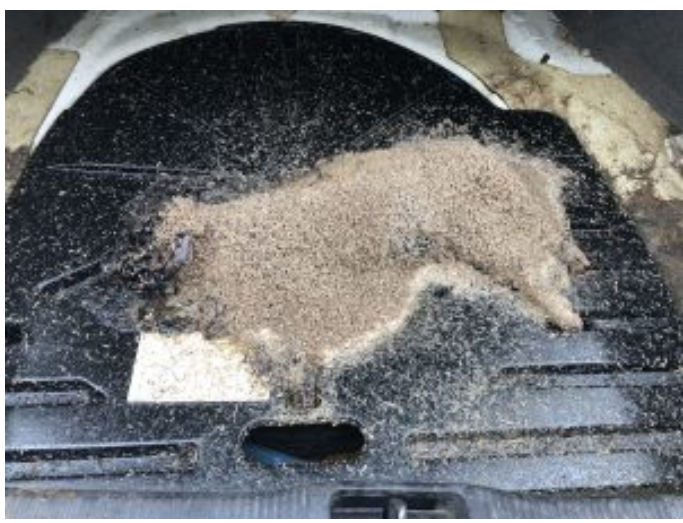

Figure 28: Trunk pig on Day 5.Photo: Emma Sidel, UNL

\section{DAY 6, JULY 7, 2019, ACTIVE DECAY AND BEGINNING OF POST DECAY STAGE}

The day was sunny and in the 70's and the team met at 8:30 a.m. There were no drastic changes today, unlike the two previous days.

\section{Observations and Actions:}

- The cistern and control pigs (Figure 29) were pretty much completely decomposed, with a few maggots and ants crawling around. The clothed pig looked like the day before.

- The maggots on the trunk pig had migrated to other areas of the car trunk. This was because the pig was mostly flesh/hide at this point with few (if any) flies.

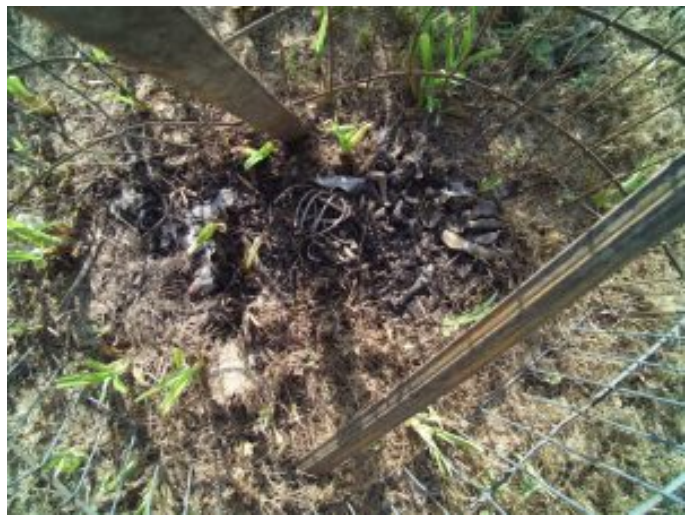

Figure 29: Control pig on Day 6, reduced to bone. Photo: Emma Sidel, UNL
A carpenter ant and a rove beetle were seen on the outside of the trunk.

- The trash bag pig had two rove beetles on the body and still had fly and maggot activity (Figure 30 ).

- The traumatized pig was completely flattened and covered with a maggot mass.

- The hanging pig looked like it was drying and had few maggots other than a few on the ground. There were very few flies remaining.

- On Day 6, a hairy rove beetle was collected from the car trunk.

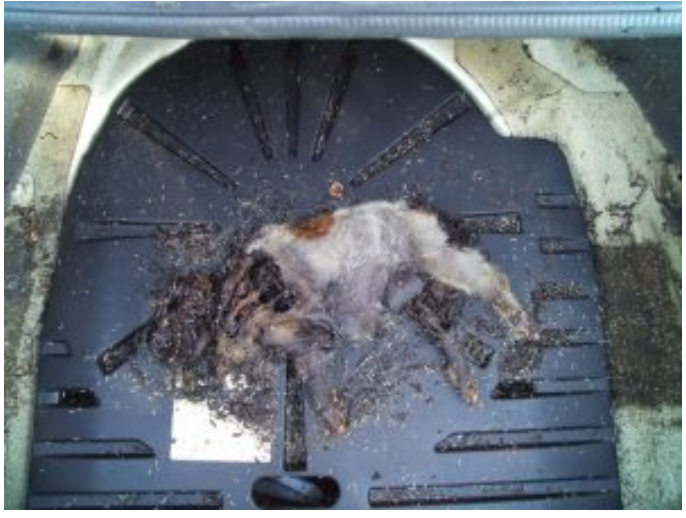

Figure 30: Trunk pig on Day 6. Photo: Emma Sidel, UNL 


\section{DAY 8, JULY 9, 2019, ACTIVE DECAY AND POST DECAY STAGE}

This was the last consecutive day that the team visited the site. The day was sunny and in the 80's. The visit occurred at noon.

\section{Observations and Actions:}

- The cistern and control pig had no real visible activity. Both were significantly decomposed with only small bits of hide and bones left, and in the case of the cistern, it was hard to see the remains. This was a good indicator to us about how it might be difficult to find a body after a certain amount of decomposition has occurred and not many insects are left.

- The hanging pig was looking even drier, and there was little insect activity.

- The traumatized pig, inside the 4 tires, had developed a wetness due to some recent rain. It, too, was primarily bones with some hair and hide. Two fly pupae were found on the body, and there were still a few stray maggots.
- The pig in the trunk had several pupae on or around the body, and maggots were still crawling around within the trunk. An unknown beetle was on top of the body; from a brief glimpse, it appeared to have a black top and light underside like a hide beetle, but it was not captured. The body still had lots of hair and hide.

- The trash bag was teeming with maggots, and the clothed pig was still the least decomposed of them all. Its head appeared intact although there was evidence of decomposition. Maggots were seen inside the sweatshirt.

- On Day 8, pupae from the trunk were collected as well as pupae from the tire trauma pig. A small grasshopper nymph was also collected in the surrounding area of the clothed pig.

At this point the team decided to wait a couple weeks before checking the status of the pigs again.

\section{DAY 16, JULY 17, 2019, POST DECAY STAGE}

In this post 8-day visit, the pigs were all nearing the end of decomposition.

\section{Observations and Actions:}

- The hanging pig had dermestid larvae seen within its anal crevice (Figure 31).

- The trunk pig was teeming with dermestid beetle larvae, along with some adult hide beetles and redshouldered ham beetles. A few maggots were still present, as well as pupae.

- The spare tire compartment under the trunk pig was removed, and a mossy substance had been soiled with decomposition fluids and many fly pupae (Figure 32 ).

- Fly pupae and dermestid beetle larvae were collected from the trunk (Figures 33 and 34).

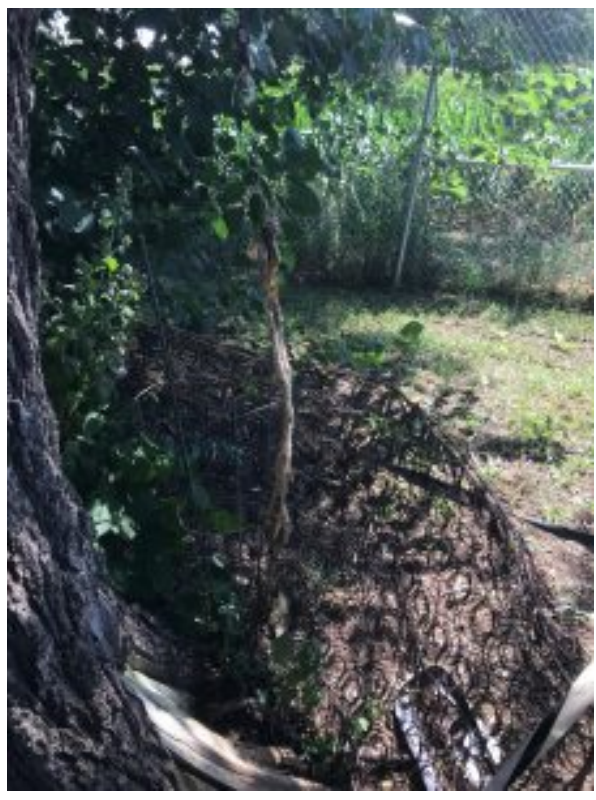

Figure 31: Hanging pig seen stretched out and reduced to hardened skin, fallen bones, and hooves. The hanging pig had looked very similar to this since Day 6. Photo: Emma Sidel, UNL 


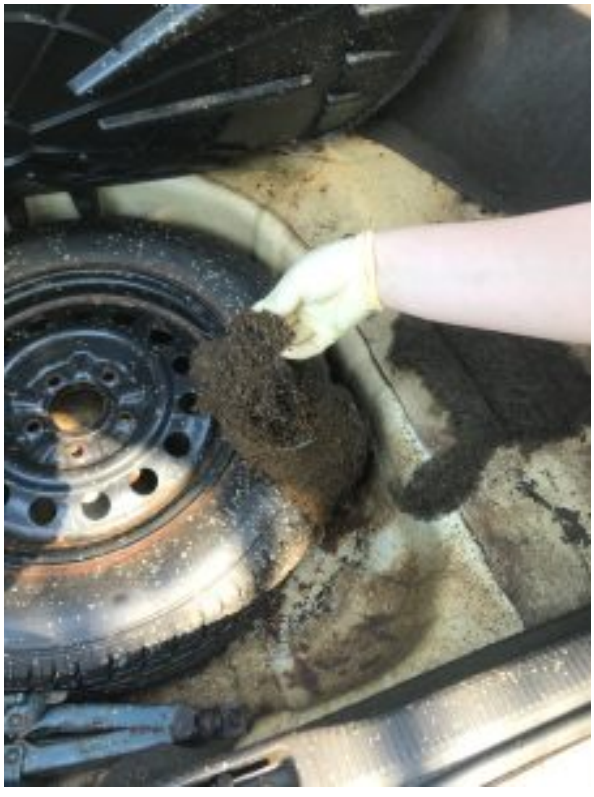

Figure 32: Fly pupae found in the spare tire compartment under the trunk pig. Photo: Emma Sidel, UNL

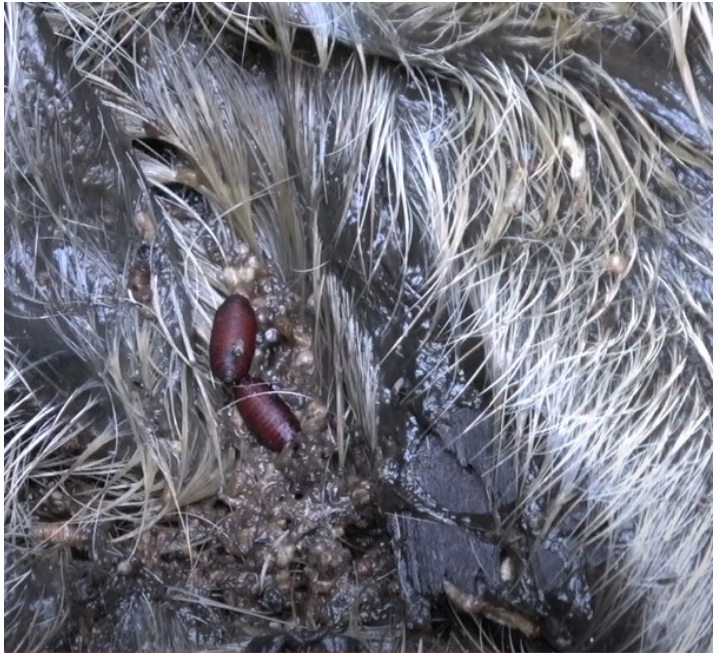

Figure 33: Fly pupae Photo: Justine LaViolette, UNL

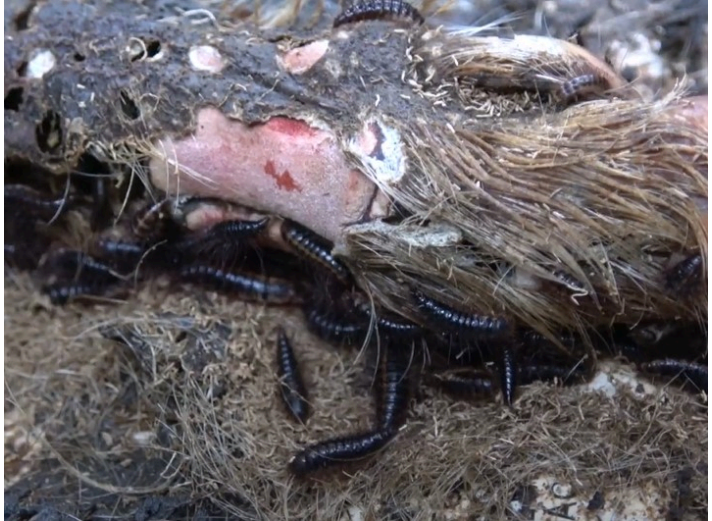

Figure 34: Dermestid larvae Photo: Justine LaViolette, UNL

\section{DAY 32, AUG 2, 2019. LAST DAY OF OBSERVATIONS, POST DECAY AND SKELETAL STAGE}

This was the final official day of observations. The weather was fairly cool in the mid 70's for most of the day.

\section{Observations and Actions:}

- The control, hanging, and cistern pigs were about the same as they were on Day 8. No or very little insect activity and in the post decay/remains or skeletal stage.

- The trunk pig still had many hide beetle larvae and adults as well as a couple red-shouldered ham beetles. Several of these insects were collected.

- The clothed pig had weeds grown completely around and over it. The researchers pulled weeds back and initially found numerous crickets all over the clothed body. The clothes were quite soiled, showing deterioration and defects due to decomposition fluids, environmental conditions, and insect activity. The hoodie appeared to be sun-bleached. When the hoodie was unzipped, primarily bones with minimal skin segments were exposed. Minimal flesh remained on the skull in which crickets and sowbugs were recovered. Even though these types of arthropods do not generally contribute to time since death estimates, it is important to collect them in order to be thorough when documenting the scene.

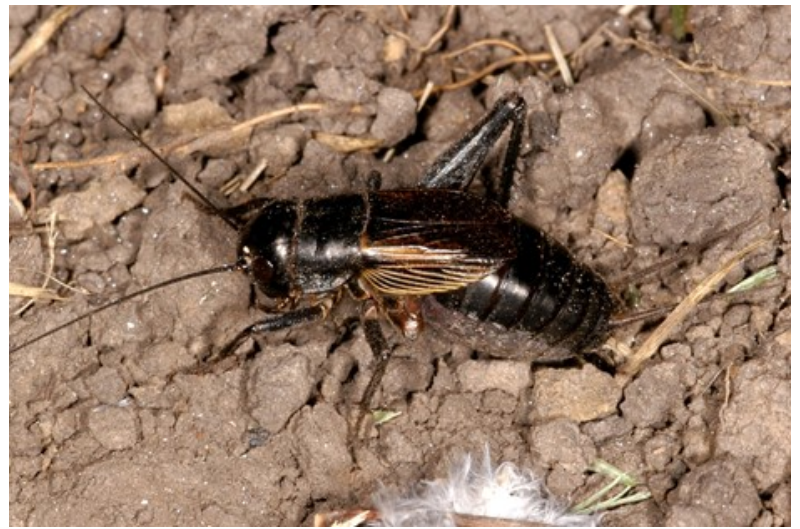

Figure 35: Field cricket Photo: Jim Kalisch, UNL 


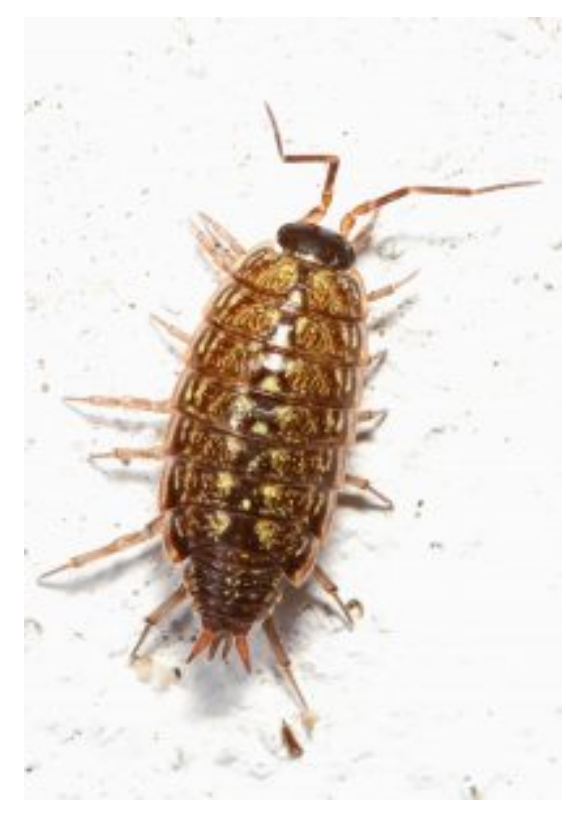

Figure 36: Sowbug Photo: Judy Gallagher Creative Commons Attribution 2.0 Generic
- The trash bag pig also had many weeds that had grown up around the bag. The bag was shoveled out and opened, where primarily bones were found. There were a lot of pupae on and in the bag as well as a few dead flies. Small rove beetle species were seen running around the bones; one was collected (see "Rove Beetles" under the Selected Forensic Insect Descriptions in this guidebook for photo examples).

- The buried pig was finally dug up. There were still no entomological indications from the outside that anything had been buried there. The researchers had trouble finding the buried pig underneath the soil, but eventually a few bones were found. The team then started looking within the dirt pile and found a large mass of a flesh/goopy substance with what appeared to be tiny eggs on it. Some of this material was collected, but the eggs never hatched. The smell was overpowering, resembling early decomposition state, likely mixed with the smell of earth.

Overall, this was a very successful project, with lots of great data collected!

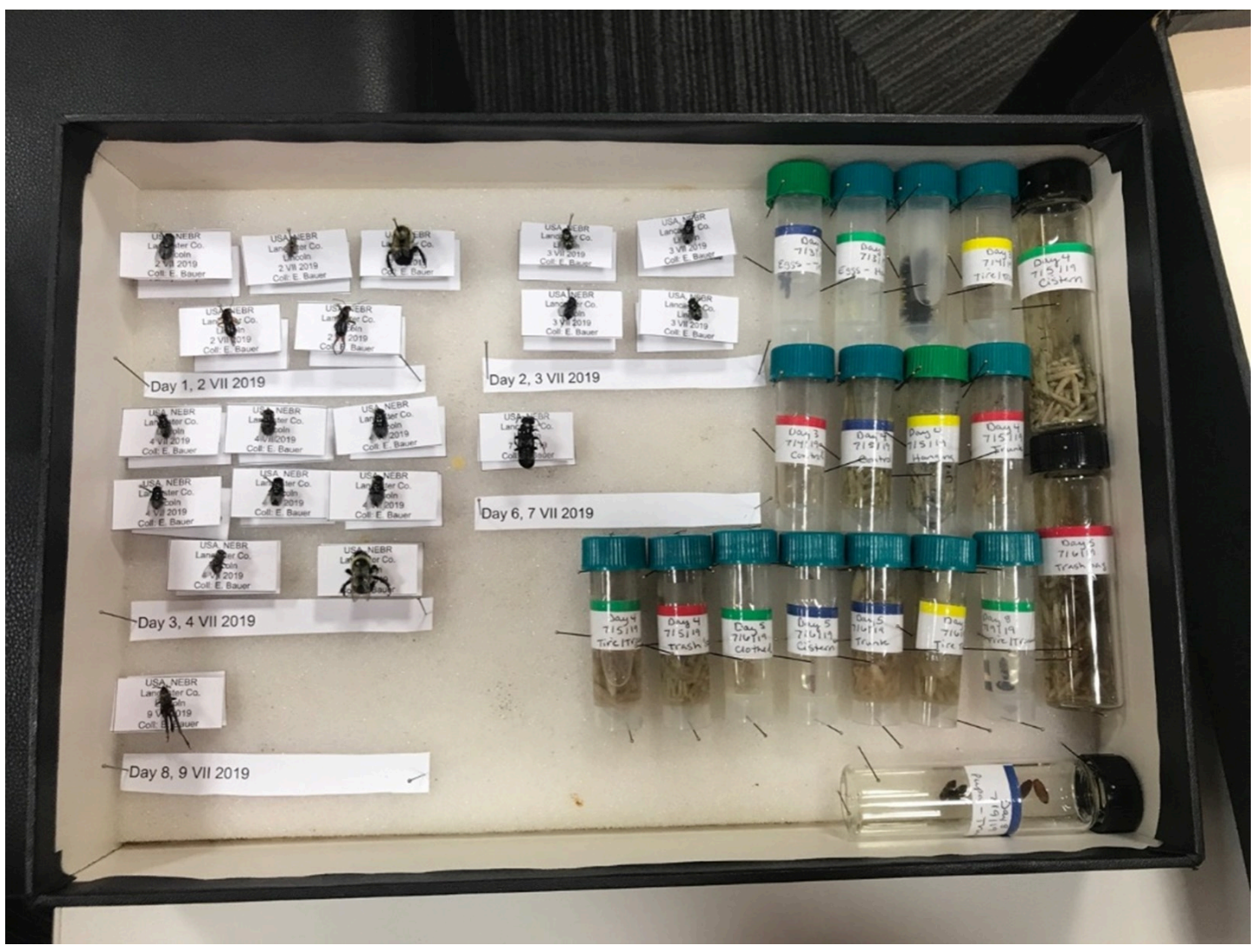

Figure 37: Pinned Insect collection including flies, beetles, and maggots. Insects collected by Erin Bauer. The collection was compiled and labeled by Emma Sidel. 

PART IV.

PROCESSING THE DEATH SCENE STEP-BY-STEP 



\section{MATERIALS}

When a body is discovered, it is important to collect any insects that may be present as evidence. This may assist you with time of death, movement of the body, manner of death, and other factors. Before arriving at a death scene, you should be sure to have the following supplies with you:

- Latex gloves

- Forceps

- Plastic spoons

- Kill jar (charged with ethyl acetate)

- Insect collecting jars or baggies

- Glass vials

- KAA (kerosene, acetic acid, ethanol mixture; optional, this can be applied back in the lab; see Step 3 for formulas and preservation techniques)

- Digital thermometer

- Camera

$$
\begin{aligned}
& \text { - Standard } \\
& \text { - Infrared } \\
& \text { - Video }
\end{aligned}
$$

- Notebook and pen

- Butterfly net

- HOBO or other temperature data logger

- Laptop Computer

- Ruler

- Specimen jars (for soil and vegetation samples)

- Urine cups for soil and debris samples

- Plastic freezer bags, $81 \frac{1}{2} \times 11$

\section{STEP 1: SCOUT THE SCENE}

Record weather conditions, temperature (using either digital or vehicle thermometer on site, or weather station data can be collected later), and time of day.
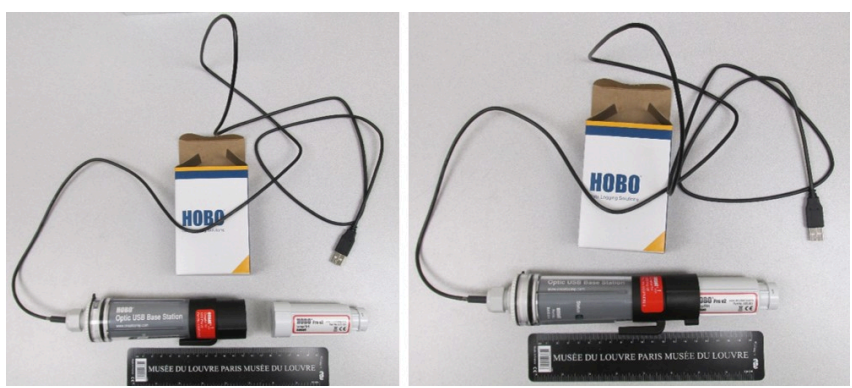

Figure 38: HOBO Data recording system using HOBO Basze U-4. Universal Optic USE Bse Station and HOBO Pro v2 Temp/RH Logger. System plugs into laptop (https://www.onsetcomp.com/search/products/HOBO.) Photo: Larry Barksdale, UNL

Approach the scene and do a visual inspection of the body, taking notes about what insects you see. These can be just general notes, as it is sufficient if you cannot identify the insect species yet; you can do that once you collect them. Be sure to note the location on the body or near the body where you see the insect activity as well as the type of weather, the temperature, and the time of day.

Also take photos from various angles of the body and close ups, if possible, of maggot masses, flies, and other insects. Use a ruler in the photos for scale. It might be beneficial to take photos using different types of cameras such as a cell phone, standard, video, and Infrared. Videos should include overall scene and close-up footage. If possible, take a 360 walk around video for 3-D imaging. In addition, take Infrared video for documentation of injury and body status.

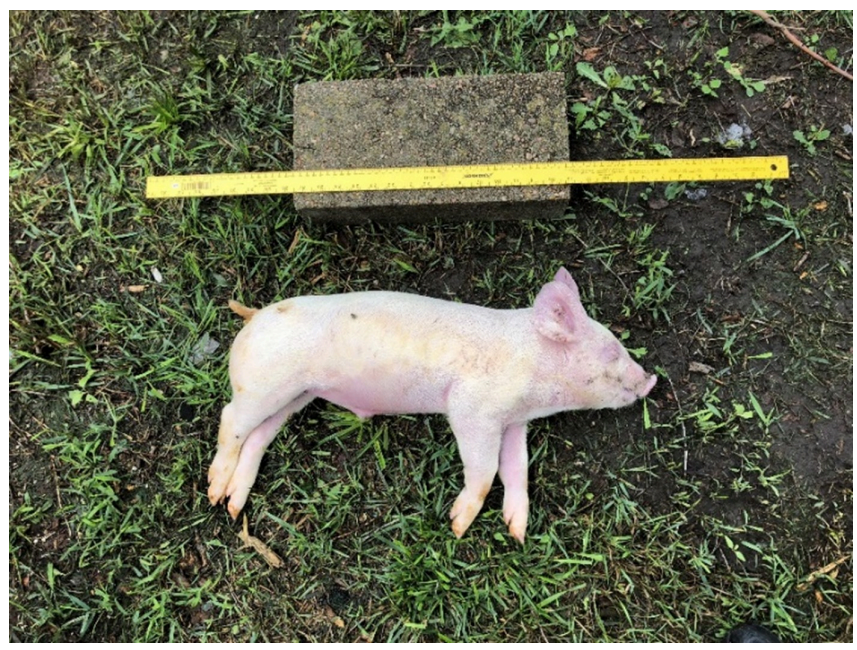

Figure 39: Photos should be taken of the corpse with a ruler to get a sense of scale and for photogrammetry purposes. Photo: Larry Barksdale, UNL. 


\section{STEP 2: FIELD COLLECTION}

Put on a pair of latex gloves and begin collecting insects.

For flying insects such as flies, wasps, or butterflies, use a butterfly net to capture them. Then place a kill jar with a lid between the insect and the netting and wait for a few minutes. The insect should then be stunned enough to remove from the net and place in the kill jar or a baggie.

For eggs and maggots, use forceps or a plastic spoon to collect eggs and maggots and place them in a vial. Be careful not to crush them and be sure to get a large sample. You can apply KAA immediately to set them (should be fixed in KAA for 30 minutes to two hours), or you can do this back at the lab. They must be fixed first in KAA before placing in alcohol or they may turn black or brown. In addition, you should collect some live maggots and rear them out to identify species and developmental times that can assist with PMI estimation.

If you have large maggot masses, use a digital thermometer to take a reading of the temperature inside the maggot mass. You should do this in masses from different parts of the body, as they may vary. Note the difference in temperature between the mass and the outside temperature.

For beetles and other ground crawling insects: You can capture ground crawling insects either directly with a regular jar or the kill jar, pick them up by hand, or use forceps, whichever method is easiest. In addition, you can set pit fall traps, which are inserted into the ground and collect falling insects as they walk over the trap.

Search at least 25 feet away from the body mass. Larvae migrate from the body mass. Look for insects on weeds, plants, trees, and structures that are near the body.

Collect soil samples away from the body mass, and eventually from under the body mass. Collect down to 12 inches. These samples can be later used by forensic taphonomists in conjunction with forensic entomologists to develop a time since death.

\section{STEP 3: LAB}

For insect preservation, the following supplies may be necessary:

- Insect pins

- Pinning board

- Display case

- Insect fumigation box (and menthol crystals; can be purchased at Amazon or other retailer)

- Vials

- KAA

- Forceps

- Microscope

- Jars or baggies to hold specimens

- Kill jars

- Gloves

Supplies can be purchased at these or other retailers:

- Amazon: (menthol crystals, baggies, gloves, etc.) - https://www.amazon.com
- BioQuip: (jars, display cases, insect pins, forceps, pinning board, etc.)

- https://bioquipinc.com/catalog/

- Wildco: (Fumigation boxes):

- https://shop.sciencefirst.com/wildco/insectfield-equipment/5904-insect-fumidor-eachplastic.html\#: :text=Also\%20known\%20as\%20a \%20fumidor,insect\%20collectsions\%20from\%2 Oliving\%20insects.

\section{- HOBO systems:}

- https://www.onsetcomp.com/search/products/ HOBO.

Once you get back to the lab, if you haven't already, you should place live adult insects either in a kill jar or in the freezer to kill them. You will then want to pin and identify these later.

Maggots should have been placed in vials at the scene. If they were put in another container first, transfer them to glass vials. Live specimens should be placed in a cooler if there is a long drive ahead to the lab; otherwise, they can continue to develop en-route. Keeping them cool will slow development.

When collecting specimens at the scene for preservation, place them in glass vials and add KAA; let this sit for 30 minutes to 2 hours, and it will help to "fix" the maggots so they will preserve well. Formulas for making KAA are below:

KAA for Insect Preservation (Sharma, Garg, \& Gaur, 2015)

95\% ethanol, 80-100 ml; glacial acetic acid, $20 \mathrm{ml}$; and kerosene, $10 \mathrm{ml}$

After the maggots have been in KAA for the allotted time, drain the KAA, and add 70\% ethyl alcohol to the vial. Alternatively, you can boil water and place maggots in this for a few minutes, drain, and then put in the alcohol. Label your vial with the date, time, and instar. Keep a record also of where you collected the maggots from the body.

See the Adams and Hall (2003) publication in the Additional References and Resources section for more detailed information about methods (boiling, KAA, etc.) for preserving forensically important insects.

You can also look at a preserved maggot to determine the instar that it is. Size can help with this, but a more definitive way is to look at the set of posterior spiracles on the rear of the insect. The number of "lines" or "slits" in the spiracles indicates the instar. The first instar has one line in each spiracle, the second two, and the third three. Determining the instar stage can help determine how long that insect has been on the body and thus help estimate time of death. If you see maggots migrating away from the body, you know these are third instar maggots.

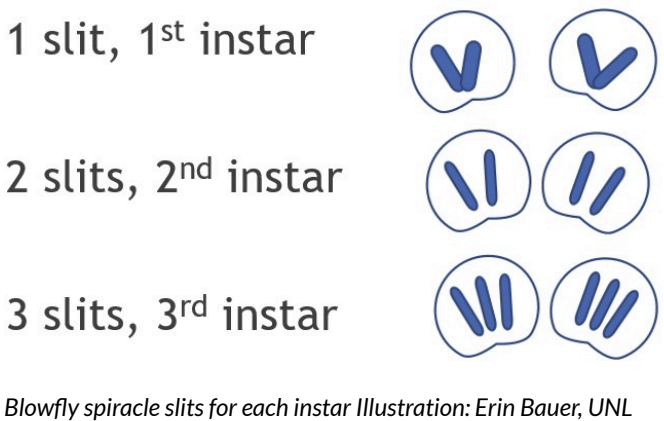




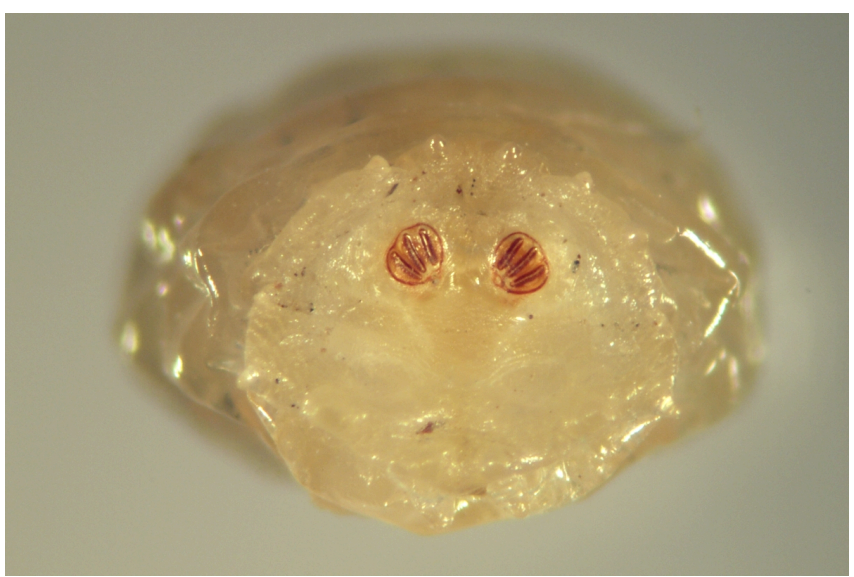

Figure 40: Blow fly third instar larvae spiracles. Photo: Jim Kalisch, UNL

\section{STEP 4: IDENTIFY}

Although you can use spiracles, hairs, and other morphological features, in general, flies are fairly difficult to identify at the larval stage. You may wish to use a dichotomous key (see Keys for Identification of Immature Insects in the Resources section). You should keep some of the maggots alive and rear them out in the lab to adulthood. Be sure to collect maggots from several locations on the body. If you have specifically seen blow flies laying eggs on the body, you can be more confident that that is the type of fly you have. But if you come to a body later where there are maggots but few or no flies, you will need to rear them out to determine species.

The rearing out process is fairly straightforward. After collecting maggots from the body at the scene, provide them with pork liver or a similar substrate as a food source (chicken doesn't work as well). Record how many days it takes for the larvae to develop into adults, and once they emerge, identify your specimens. A dichotomous key, which breaks out morphological features into couplets to narrow down to an insect order, family, or species, can be useful in helping identify insects. See the References and Resources list at the end of this guidebook for materials that can help with this. You may also wish to consult with a trained forensic entomologist if you are unsure of how to identify certain specimens.

Other adult insects can be identified after collection. Common insects may be flies (i.e., the blow flies and flesh flies), beetles (predatory, carrion, or dermestids, depending on state of decomposition), and other miscellaneous arthropods that may be preying on maggots or that are opportunistic. These may include butterflies, spiders, cockroaches, ants, wasps, and earwigs.

\section{STEP 5: DEATH STUDIES}

Insects collected from a body can help in many different areas at a death scene:

\section{Estimated Time of Death/PMI (Postmortem interval):}

Blow flies are often the "first responders" at a death scene because they are attracted to the odors emitted by dead organisms. If a fresh body is accessible, flies usually visit it within minutes and lay their eggs in a fairly short time frame (minutes to hours). Eggs generally hatch in 18-20 hours, depending on temperature, so the age of the maggots that are found (first, second, or third instar) on a corpse can be helpful in estimating time since death (PMI).

For example, in the pig research study, the researchers saw a small number of blow flies within a few minutes of placing the pig in the field (time of colonization) and considerably more the second day. They first observed maggots on Day 3 in the mid-afternoon which were primarily first instar with a few second instar larvae. Therefore, the maggots likely hatched sometime on Day 2. By Day 5, the corpses had a lot of third instars and by Day 8 almost all the maggots were migrating. Because the researchers were able to observe the piglets daily, they could make good estimates about the progression of insect activity and how it related to PMI and decomposition.

However, it is important to note that while this is a good foundation for understanding general decomposition processes and how insect activity relates to them, each reallife situation is distinct. For example, the piglets were all under $20 \mathrm{lbs}$. Unless it is a very young child, most human victims will have more body mass and thus decomposition rates will be different, even if the body is found in a similar setting as the research study (outdoors in the heat of summer, with little rain). Although time of colonization (assuming the corpse is accessible) is usually shortly after death, it is important to remember that many conditions, such as temperature, location, season, and weather patterns are variable and can influence insect activity, including delaying, accelerating, or slowing it down. Investigators should always take every factor into consideration when estimating time since death because each case is unique.

\section{Manner of Death:}

Insects can help provide clues about how a person died. Some examples include:

Wounds: Blow flies congregate towards natural openings like the mouth, eyes, nose, and anus. If another area of the body has a large number of maggots, it may be possible that this is a wound area, such as a stab wound or a gunshot wound. It is also important to consider that the presence of an additional opened area is going to accelerate the decomposition process, making the decomposition stages shorter than in a natural death.

Toxicology: In some cases, a person may have died not by murder, but by overdose or another drug related incident. If such a death is suspected, investigators can collect maggots feeding on the body and test them for traces of drugs. This can help identify if someone had drugs in their system. In addition, the presence of drugs can often affect the rate of larval development...speeding it up or slowing it down. For example, cocaine accelerates larval development (time to reach pupation is thus shorter), while barbiturates decrease development (time in larval stage is longer, thus reaching pupation takes longer) (Verma \& Reject, 2013). Therefore, drugs can affect postmortem estimations.

Location of Death: Where human remains are found does not always represent the actual crime scene. In order to hide their crime or confuse investigators, sometimes suspects will move the body to a different location from where they murdered the victim. Insects can actually aid in determining if a body has been moved by understanding their ecology and their geographical distribution.

For example, some flies are attracted to more sunny areas 
while others are attracted to shady areas. Some insects prefer cooler areas, while others like warmer areas. For example, if a body is found in a shady location with insects from a species that prefers sun, it's likely that the body was moved at some point. Or if a body is found in a dry, sandy area, but there are insects found on the body that are usually found in moister, grassy areas, that could indicate movement. In general, if an insect is found in or around a body and is unusual or unknown in the location where the body is discovered, then movement might be suspected.

A well-known case involving potential movement of a body was with the Casey Anthony case. Part of the evidence of Anthony's guilt hinged upon if and for how long Caylee Anthony had been stored in the trunk of Casey's car before being moved elsewhere. Both the defense and the prosecution hired forensic entomologists to testify for them, one trying to indicate that it had been trash, rather than a body, in the trunk, and the other trying to show that Caylee's body had been there and what insect evidence showed it. Casey Anthony was not convicted, and although the ruling is still controversial, forensic entomology served to provide important evidence in the case (Crime Museum, n.d.).

Suspect Identification: Insects have helped in cases where a suspect lied about their whereabouts, claiming they were not in the vicinity when the victim died, but the insect evidence showed otherwise. One prime example is when insects are found in or on a suspect's car (such as dead insects in the car or insects stuck in the grille), and these are species that are common only to a particular region, usually the region where the victim was killed or not native to the region where the suspect claims to have been.

Another interesting way that insects or related arthropods can help in suspect identity is by collecting DNA from blood sucking insects found at a scene. Arthropods such as mosquitoes, ticks, or lice found on a body may have blood from the suspect as well as blood from the victim. For example, crab lice found on a rape victim may have come from the suspect and analyzing the DNA within those lice could lead to the suspect.

An example where insects helped in suspect identity was with the Vincent Brothers case. Vincent Brothers' ex-wife, mother-in-law, and children were murdered in California. Brothers had gone to Ohio to visit his brother and claimed he was still there when the crime occurred. However, insects found in the grille of Brothers' rental car uncovered species that were only found in CA and/or specific areas of CA, or other states between $\mathrm{OH}$ and $\mathrm{CA}$. This proved that Brothers traveled from $\mathrm{OH}$ to $\mathrm{CA}$ to commit the murders and back again, and therefore insect evidence played a significant role in convicting Brothers (Parker, 2007). 
PART V.

\section{CONCLUSION}

Insects found at death scenes are important evidence that can aid law enforcement in determining time, manner, and location of death and even potential suspect identity. Insects colonize bodies in a fairly predictable pattern based on geographical and temporal locations, so the types of insects found at a scene can help estimate PMI. Blow fly larvae (maggots) are one of the best indicator species for death scene investigations as they arrive within minutes of death and develop through three larval stages (instars) during fresh, bloat, and active decay, with the third instar migrating from the body.

A pig study at UNL demonstrated ideal conditions (outdoor, open, hot, and sunny) for larval development, with decomposition close to completion (only hide and bones remaining) at 8 days with the majority of maggots migrating away from the body to pupate. This can be used as a baseline for maggot involvement on a corpse, but law enforcement should keep in mind that other factors such as cooler temperatures, heavy rains and winds, indoor environments, and wrappings such as blankets or tarps may influence decomposition patterns and insect development. The impact of weather conditions was apparent in the UNL follow up pig study where heavy rains sped up decomposition and on the 8th day, very few maggots were seen migrating, or even at all. The piglets were also primarily bones, with little hide left, which is unlike what was seen in the original study.
Investigators should be prepared to collect insect evidence at a death scene, if available, regardless of the state of the corpse. Earlier in decomposition, in the fresh, bloat, and active stage especially, maggots will be present in large numbers and, depending upon on their age and where on the corpse they are located (i.e. natural openings, wound, etc.), these insects can help in PMI estimation. Maggots of all sizes should be collected and preserved, identified, aged, and in some cases reared out to record developmental time.

Beetles appear in later stages and can also be helpful in death studies. Predatory insects, such as earwigs, wasps, or ants, may also be present and feeding on maggots. Samples of any insects or other arthropods, such as spiders, that are found on or near the body should be collected since they can potentially offer clues.

This guidebook has discussed various aspects of how forensic entomology can aid law enforcement. This includes the types of insects found on bodies, at what stage during composition they are found, and how to collect and preserve them. Overall, insect evidence should be considered an integral part of the toolbox when processing scenes during criminal investigations. When in doubt about the identity of your collected insects or if you have other questions related to your insect evidence, you should consult with forensic entomology experts to help aid your investigation. 

PART V.

\section{APPENDIX A: FORENSIC ENTOMOLOGY EXERCISES}

This section includes practice exercises to test your knowledge about insect evidence at crime scenes and is divided up by topical areas such as Insect ID, Collecting and Preserving, Insect Artifacts, and Case Studies. It also includes exercises where you might read and review scientific literature or develop presentations. This may be useful for forensic or entomology students, educators teaching or consulting as forensic entomologists, and law enforcement personnel responsible for forensic entomology training who would like some practical applications of forensic entomology. Some additional research beyond this manual may be needed for some of these exercises. 



\section{FORENSIC INSECT SUCCESSION CASE STUDIES}

(Insect Evidence use for Time since death, Manner of Death, Location of Death, Movement of Body, and Suspect Identity)

1. For this experiment, find a motor vehicle (such as your own, a family member's, or coworker's) that has been driven for several days on an interstate or other similar highway. Examine the vehicle, especially the windshield and grille, for insects and insect parts. Do not forget to look under the hood. Identify and record the insects and parts you located. Your identification should include photographs and explanations for the natural habitat and/or U.S. states where these insects might be found (i.e., hot/cold environment or specific ecosystem like forest, urban, rural, etc.). Use this information to write up an argument about the locations where the vehicle may have traveled.

2. Discuss the concept of uncertainty and error in determining insect succession at a crime scene, and how uncertainty and error would affect a determination of location and time since death. Prepare a PowerPoint presentation that could explain this concept to others.

3. The prosecuting attorney on a homicide case wants you to explain in court how cognitive bias could affect a forensic entomologist's conclusions concerning the succession of insects and the locations of the body prior to death. The victim was a transient man who had come from Iraq two weeks prior to being found next to a railroad track in Lincoln, Nebraska. He had been beaten and shot in the back of the head. It was estimated he had been deceased for two days. He had originally arrived in Omaha from Iraq.

4. Your supervisor has handed you the following book: Cruz, A.M. (2006). Crime scene intelligence: an experiment in forensic entomology. The National Defense Intelligence College Press. You have had several decomposition cases in the past couple of years and your supervisor has called a meeting of regional law enforcement officers, crime scene investigators, and forensic scientists. She wants to explore retaining a forensic entomologist as a consultant. She has asked you to prepare a PowerPoint presentation based on the preceding article and any other information sources you see fit to include in the presentation. She specifically asks that you address the concept of insect succession and how investigators and scientists can use it to determine important investigative information.

5. Use the information from the following articles to discuss how different environments affect insect succession. Create a short summary paper on the topic.

- Lynch-Aird J et al. (2005). "Decomposition Rate and Pattern in Hanging Pigs. "Journal of Forensic Sciences September 2015 60(5). doi: 10.1111/1556-4029.12796. 
- Forman B (2015). “The Greenhouse Effect: Decomposition Rates in Human Remains Wrapped in Plastic. Master Thesis." University of Tennessee, Knoxville. August 2015.

- G. Simpson \& D. B. Strongman (2002) "Carrion Insects on Pig Carcasses at a Rural and an Urban Site in Nova Scotia," Canadian Society of Forensic Science Journal, 35:3, 123-143. doi: 10.1080/00085030.2002.10757541

6. Read the following scientific article: De Jong, G. and Hoback, W. (2006). "Effect of Investigator Disturbance in Experimental Forensic Entomology: Succession and Community Composition." Medical and Veterinary Entomology. 20, 248-258. doi: 10.1111/ j.1365-2915.2006.00618 x.

Write a short paper answering the following:

1. Does investigator disturbance affect insect succession at a crime scene? Thoroughly explain your answer.

2. Does investigator disturbance affect time since death determinations? Explain your answer.

3. What other research has been conducted in this area? Explain how it pertains to the research in this article.

4. What alternatives are there to investigator disturbance such that sufficient evidence and data could be gathered to describe the crime scene? 
1. Create a table that outlines information about the lifecycle of blow flies, flesh flies, and house flies, including maggot and adult identification (include photos), adult reproductive behavior, growth times for each instar, developmental factors, stage of decomposition when these flies are present, and importance in determining PMI.

2. Identify four insects in the family Diptera that would be at a crime scene. Explain how each would be useful in establishing a time since death. Include photographs and identification techniques for each insect.

3. Identify four predatory insects that could be found at a crime scene. How would these insects affect the insect succession at the scene? What factors would affect the presence of these insects? Include photographs and identification techniques for each insect.

4. Write a short paper on insects that are not as forensically common at a crime scene. Include photographs and techniques for identification of each insect.

5. Prepare a table that indicates the forensically important insects at a crime scene, the times they would be expected, identifying characteristics, a photograph, and factors affecting their appearance at a scene. 


\section{COLLECTING AND PRESERVING INSECTS AT CRIME SCENES}

1. You arrive at a scene on a sunny June afternoon. It's $85^{\circ} \mathrm{F}$ and humid. A female body is in an open field near a park. She does not physically appear like she's been dead long, but as you look more closely, you see some small maggots coming from her mouth and nose. You also notice some flies landing often on the body and in addition to flying near her nose, ears, and mouth, seem to be congregating around the back of her head. How would you collect and process the insect evidence found at this scene?

2. Prepare a PowerPoint presentation or short paper on how to document and preserve insects found at a crime scene.

3. Create a $\log /$ record sheet that you can take with you to a crime scene for collecting and preserving insect evidence. Include date, time, temperature, insect ID, tools, collection and/or preservation method used, and any additional information important to your situation. 


\section{BLOODSTAINS/INSECT ARTIFACTS}

Insect specks (feces) can often be found at a crime scene on walls and other materials and be mistaken for blood spatter. These exercises will help you think more about this process. See Rivers and Geiman (2017) in the References and Resources section to read more about this topic.

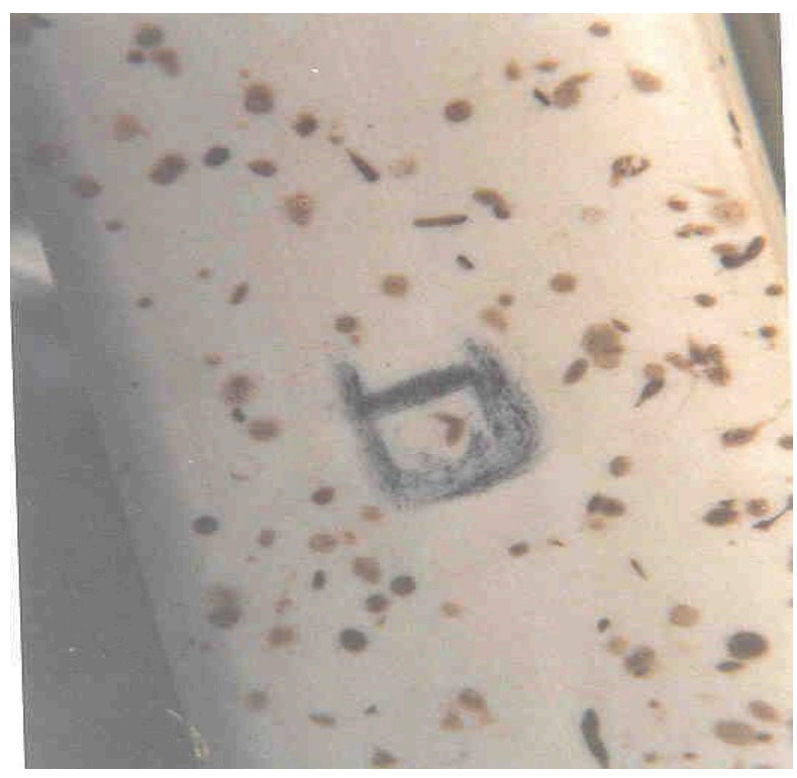

Fly specks on window shade. Photo: Larry Barksdale, UNL

1. Place a piece of pork liver or another suitable item on a nonporous surface. Fold sheets of typing paper to form a cylinder. Place the cylinder around the meat. You will need to secure the cylinder and meat so that it is not taken away by predators. Examine the set-up daily. Take photos and record insects you observe at the scene. After 3 days, take down the cylinder and photograph its surface. Compare marks on the cylinder with bloodstain patterns and write up a summary of the differences.

2. Your supervisor has asked you to explain the marks that simulate bloodstains and/or insect activity at a crime scene. Find scientific literature and/or conduct a personal experiment(s) to describe the marks that could be found at the scene of a deceased human body and create a 1page summary about this topic. 


\section{POSTMORTEM INTERVAL (AKA TIME SINCE DEATH)}

1. Explain in a short paper the advantages and challenges of the Vass "universal" formula for determining PMI. You may wish to consult the following article for reference: Vass, A.A. (2011). The elusive universal postmortem interval formula. Forensic Science International.

2. Read the following journal article: Nabity, P., Higley, L. \& Heng-Moss, T. (2006). Effects of temperature on development of Phorimia regina (Diptera: Calliphoridae) and use for developmental data in determining time intervals in forensic entomology. Journal of Medical Entomology 43(6): 1276-1286. Write a literature review to present research that has been done in this area since the publication of the reference article. Explain anything that has changed, new information, and development of procedures.

3. Review the following scientific articles. In a short paper, explain how one technique would or would not corroborate another technique in establishing a time since death.

- Shukla, G. (2018). Establishment of PMI through succession of presence of beetle in forensic investigation. Academic Journal of Forensic Sciences. 01 (02) October 2018, 30-35.

- Maile, A. et al. (2017). Toward a universal equation to estimate postmortem interval. Forensic Science International 272 (2017) 150-153. https://dx.doi.org/10.1016/ j.forsciint.2017.01.013.

- Megyesi, M et al. (2005). Using accumulated degree-days to estimate the postmortem interval from decomposed human remains. Journal Forensic Science, May 2005, 50(3).

- Catts, E. (1992). Problems in estimating the postmortem interval in death investigations. Journal of Agricultural Entomology. 9(4). 


\section{INSECT COLOR PREFERENCE}

Your forensic professor is curious about if flies are more attracted to one color of clothing than another and if this affects visitation to a particular body. Review scientific literature to find out which colors may be more attractive to forensically important flies. You may wish to begin with this article:

- Benelli, G., et al. (2018). High innate attractiveness to black targets in the blue blowfly, Calliphora vomitoria (L.) (Diptera: Calliphoridae). Acta Tropica 182 (2018) 144-148. https://doi.org/10.1016/j.actatropica.2018.02.023. 

PART VI.

\section{APPENDIX B: FORMS AND EXERCISES}





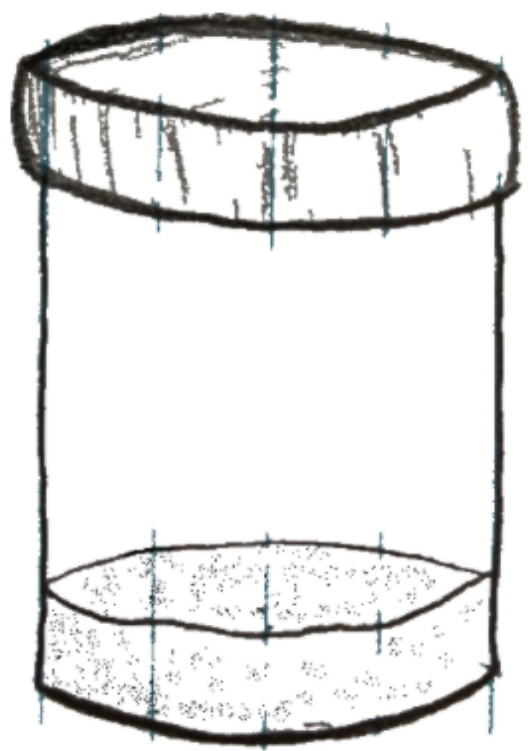

\section{CREATING A KILL JAR}

1. Select a clean glass jar with a wide mouth and a screw cap that is $160 z-320 z$ in size. Do not use plastic.

2. Fill the bottom of the jar with approximately 1" wet Plaster of Paris (mixed according to directions on package).

3. Once the plaster is hardened, place jar into oven on warm until thoroughly dried.

4. After oven removal, saturate the plaster with Ethyl Acetate (available in most drug stores) and pour off excess liquid not immediately absorbed. Place the screw cap tightly on the jar.

5. Keep the jar tightly capped to prolong effectiveness. Once kill time is no longer quick, dry out the jar and recharge by applying more Ethyl Acetate. 
SCENE COLLECTION NOTES WORKSHEET 
Prepared By

Date

Case Number

Scene Notes

Temperature

Time

Weather Conditions

Body Notes

Age Weight

Sex

$\square$ Indoor $\square$ Outdoor Other

Location

State

Position

$\square$ Fresh $\square$ Bloat $\square$ Active $\square$ Dry $\square$ Remains

Defects Present Defect Description
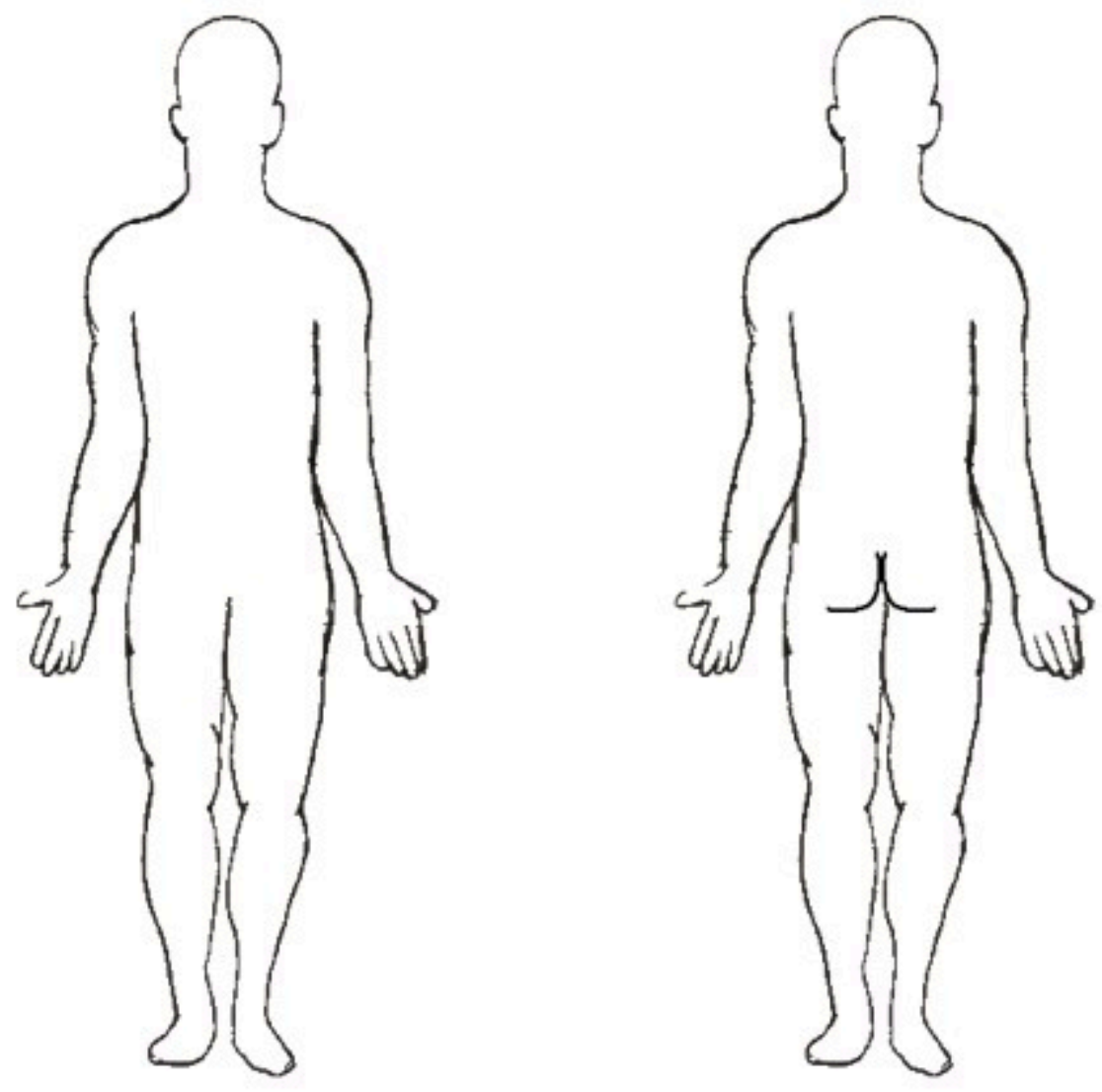


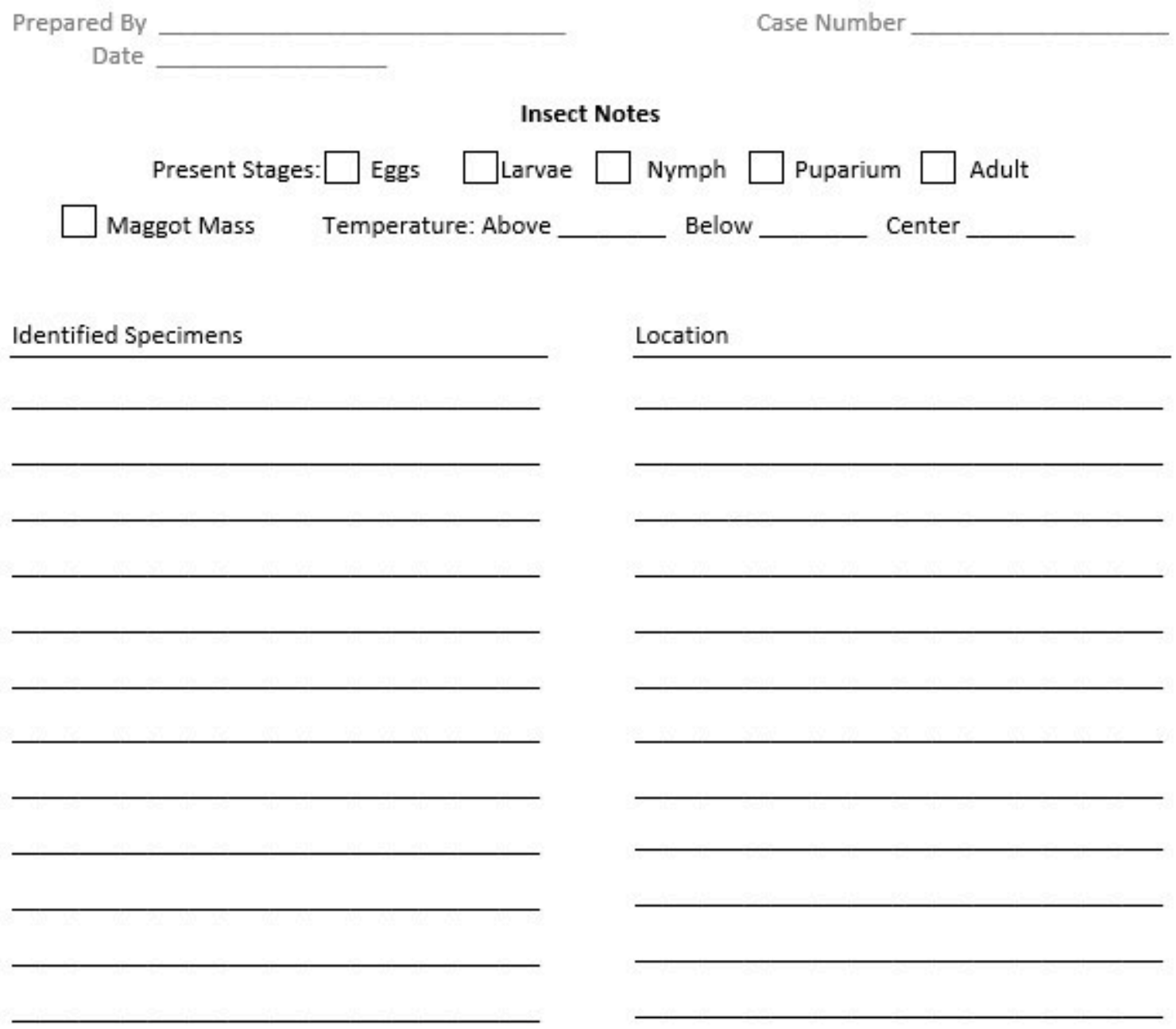

Activity Observations 


\section{ADDITIONAL REFERENCES AND RESOURCES}

- Adams, ZJO \& Hall, MJR (2003). Methods used for the killing and preservation of blowfly larvae, and their effect on postmortem larval length. Forensic Science International. 138: 50-61.

- Amendt, J., Campobasso, C.P., Gaudry, E., Reiter, C., LeBlanc, H.N., \& Hall, M.J.R. (2006). Best practice in forensic entomology-standards and guidelines. International Journal of Legal Medicine.

- Nebraska Game and Parks. American Burying Beetle. Retrieved November 5, 2020 from http://outdoornebraska.gov/americanburyingbeetle/

- Anderson, M. \& Kaufman, P.E. Featured Creatures: Common Green Bottle Fly. University of Florida. Retrieved from http://entnemdept.ufl.edu/creatures/livestock/flies/ lucilia_sericata.htm

- Australian Museum. Stages of Decomposition. Retrieved from https://australianmuseum.net.au/stages-of-decomposition

- Beneke, M. (2001). A brief history of forensic entomology. Forensic Science International. 120: $2-14$.

- Choate, P.M. (2003). Introduction to the Identification of Insects and Related Arthropods. Retrieved from https://entnemdept.ufl.edu/choate/insectid.pdf

- Cochran, S. (2015). Carpenter Ant Identification Resources. Nebraska Extension in Lancaster County. Retrieved from https://lancaster.unl.edu/pest/ants/cants.shtml

- Crime Museum. (n.d.) Forensic Analysis of the Casey Anthony Trial. Retrieved July 6, 2021 from https://www.crimemuseum.org/crime-library/forensic-investigation/forensic-analysisof-the-casey-anthony-trial/

- Department of Entomology Biological Control Information Center. Rove Beetle. North Carolina State University. Retrieved from http://www4.ncsu.edu/ dorr/Insects/Predators/ Rove\%20Beetles/rove_beetle.html

- Diaz, L.A. \& Kaufman, P.E. Featured Creatures: Flesh Fly. University of Florida. Retrieved from http://entnemdept.ufl.edu/creatures/misc/flies/sarcophaga_crassipalpis.htm

- Encyclopedia Britannica. Thread-waisted wasp. Retrieved from https://www.britannica.com/ animal/thread-waisted-wasp

- Forensics Library. Decomposition. Retrieved from https://aboutforensics.co.uk/ decomposition/ 
- Gennard, D. (2012). Chapter 11: Investigations in an aquatic environment. Forensic Entomology: An Introduction. 2nd ed. Wiley-Blackwell. 169-183.

- Hall, D.W. Featured Creatures: Question Mark. University of Florida. Retrieved from http://entnemdept.ufl.edu/creatures/bfly/bfly2/question_mark.htm

- Insect Identification for the Casual Observer. Nebraska Insects. Retrieved from https://www.insectidentification.org/insects-by-state.asp?thisState=Nebraska

- Iowa State University Extension and Outreach. "Earwigs." Horticulture and Home Pest News. Retrieved from https://hortnews.extension.iastate.edu/earwig

- LeBlanc, H.N. (2017). Forensic Entomology Collection Manual. University of Ontario Institute of Technology.

- Mahr, S. Rove Beetles. Master Gardener Program. University of Wisconsin Extension. Retrieved from https://wimastergardener.org/article/rove-beetles-staphylinidae/

- Moore, M.R. \& Kaufman, P.E. Featured Creatures: Hister Beetle. University of Florida. Retrieved from http://entnemdept.ufl.edu/creatures/beneficial/beetles/ Carcinops_pumilio.htm

- MuseumPests.net (2015). Red-legged Ham Beetle. Retrieved from https://museumpests.net/ wp-content/uploads/2015/05/Fact-Sheet-Redlegged-Ham-Beetle.pdf

- Parker, C.B. (2007). Buggy: Entomology prof helps unravel murder. U.C. Davis. Retrieved from https://www.ucdavis.edu/news/buggy-entomology-prof-helps-unravel-murder

- Ratcliffe, B. C.(1996). Carrion Beetles of Nebraska. Bulletin of the University of Nebraska State Museum. Volume 13.

- Rivers, D. \& Dahlem, G.A. (2014). The Science of Forensic Entomology. Wiley-Blackwell.

- Rivers, D. \& Geiman, T. (2017). Insect Artifacts Are More than Just Altered Bloodstains. Insects 2017, 8, 37; doi:10.3390/insects8020037.

- Sharma, R, Garg, RK, \& Gaur, JR. (2015). Various methods for the estimation of postmortem interval from Calliphoridae: A review. Egyptian Journal of Forensic Sciences. 5, 1-2.

- Shaver, b. \& Kaufman, P.E. Featured Creatures: Hide Beetle. University of Florida. Retrieved from http://entnemdept.ufl.edu/creatures/misc/beetles/hide_beetle.htm

- Texas A \& M Agrilife Extension. Blow Fly. Field Guide to Common Texas Insects. Retrieved from https://texasinsects.tamu.edu/diptera/blow-fly/

- Thyssen, P. (2010) Keys for Identification of Immature Insects. In Current Concepts in Forensic Entomology. Pg 25-42. Retrieved from https://www.researchgate.net/publication/ 226782686_Keys_for_Identification_of_Immature_Insects

- Verma, K. \& Reject, P. (2013). Assessment of postmortem interval, (PMI) from forensic entomotoxicological studies of larvae and flies. Entomology, Ornithology \& Herpetology. 


\section{BOOKS AND OTHER MEDIA ABOUT FORENSIC ENTOMOLOGY OR FORENSIC INSECT IDENTIFICATION}

- Byrd, J.H. \& Castner, J.L. (2010). Forensic Entomology: The Utility of Arthropods in Legal Investigations. 2nd ed. CRC Press.

- Byrd, J.H. \& Tomberlin, J.K. (2020). Forensic Entomology: The Utility of Arthropods in Legal Investigations. 3rd ed. CRC Press.

- Erzinclioglu, Z. (2000). Maggots, Murder, and Men. St. Martin's Press.

- Gennard, D. (2012). Forensic Entomology: An Introduction. 2nd ed. Wiley-Blackwell.

- Goff, M.E. (2000). A Fly for the Prosecution; How Insect Evidence Helps Solve Crimes. Harvard College.

- Kimbirauskas, RK, Merritt, RW, Tomberlin, JK, Benbow, ME \& Wallace, JR. Forensic Entomology: Collection and Preservation of Insect Evidence for Crime Scenes.

- Rivers, D. B. \& Dahlem, G.A. (2014). The Science of Forensic Entomology. Wiley Blackwell.

- Schotsmans, EM.J., Marquez-Grant, N., and Forbes, S.L. Eds. (2017). Taphonomy of Human Remains: Forensic Analysis of the Dead and the Depositional Environment.

- Triplehorn, C.A. \& Johnson, N.F. (2005). Borror and DeLong's Introduction to the Study of Insects. 7th ed. Brooks/Cole. 


\section{GLOSSARY}

Adipocere or Corpse Wax: a grayish waxy substance created in fatty tissues of a dead body by anaerobic bacteria and formed by the decomposition of soft tissue subjected to moisture.

Arthropods: invertebrate animals having an exoskeleton, segmented body, and paired jointed appendages.

Autolysis: cellular breakdown.

Carrion: decaying flesh of dead animals, often a food source for insects.

Carrion Beetles: beetles that feed on decaying flesh of animals.

Cerci: (plural of cercus) a small appendage at the base of the abdomen of some insects which occurs in pairs.

Complete Metamorphosis: development of an insect with four distinct life stages including egg, larva, pupa, and adult. The larval stage may have multiple instar stages prior to becoming an adult.

Dermestid Beetles: beetles that feed on dead skin cells.

Dichotomous Key: a pictorial tool used to identify insects by physical characteristics in a branching manner.

Elytra: each of the two hardened outer wing casings of a beetle.

Forensic Entomology: scientific study of insects and their use in legal investigations.

Kill Jar: a device used to kill captured insects quickly with minimal damage. Typically this is a sealable glass jar with a layer of Plaster of Paris at the bottom to absorb the killing agent.

Larval Instar: developmental stages of insect larval forms of complete metamorphosis; each instar stage is numbered (i.e. 1st, 2 nd, 3 rd, etc.) until the adult form is revealed.

Mottling: blotchy, red-purplish marbling of the skin due to lack of blood flow.

Myiasis: a body infestation of fly larvae (maggots) which grow in living tissue while feeding on the host.

Predatory Arthropods: invertebrate animals having an exoskeleton, segmented body, and paired jointed appendages (arthropod) which feeds on similar arthropods. This may include, but is not limited to, wasps, earwigs, beetles, and ants.

Posterior Spiracles: external respiratory openings located on the back end of an insect.

Post mortem interval (PMI): time since death; insect colonization and larval development can be helpful for estimating PMI in forensic investigations.

Pupa: a life stage experienced by insects who undergo complete metamorphosis, a transformation from larva to adult.

Pupate: (verb) during this process, the last instar stage of a larva becomes a pupa and will later emerge as an adult. 


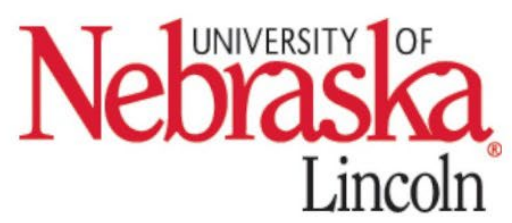

